\title{
ESPECTROS DEL NEOLIBERALISMO. ECONOMÍA DE TRASPATIO Y NECROPOLÍTICA EN MÉXICO
}

\section{Humberto Márquez Covarrubias*}

Resumen: En el concierto del capitalismo mundial, la economía mexicana es presentada como una de las más grandes y dinámicas. Destaca la exportación de productos maquilados (automóviles, electrónicos y aeroespaciales) y materias primas (minerales, petróleo y alimentos), aunque también de drogas y migrantes. En realidad funge como teatro de operaciones del capital rentista que orquesta megaproyectos extractivos, especuladores, maquiladores y criminales donde fluyen grandes cantidades de dinero y son acumuladas enormes fortunas, además de que el trabajo es precarizado y la naturaleza depredada. Un rasgo estructural es la transferencia del excedente hacia los centros de la economía mundial mediante el pago de deuda externa, remesas de ganancias, regalías, comercio intrafirma y fuga de capitales. La oligarquía ha sido beneficiada por la privatización y transferencia de recursos públicos; en tanto la clase política gestiona el proyecto neoliberal mediante la dominación y la violencia. El modelo económico tiene como trasfondo el expolio del fondo de vida obrero, la pauperización del pueblo, el despojo de bienes nacionales y comunales además de la abrogación de conquistas laborales y derechos sociales. En ese ámbito pervive una economía anclada al desvencijado mercado interno y la subsistencia familiar que permanece estancada y bajo acoso permanente.

palabras Claveः capitalisno, neoliberalismo, Estado, crisis, México.

*Docente-investigador de la Unidad Académica de Estudios del Desarrollo de la Universidad Autónoma de Zacatecas, México. 
Abstract: Within the world capitalist order, the Mexican economy is presented as one of the largest and most dynamic. This encompasses the export of manufactured products (automobiles, electronics, aerospace) and raw materials (minerals, petroleum and agricultural products), but also drugs and migrants. In reality, it is the theatre of operations of rentier capital, which operates extractive and speculative megaprojects, maquiladoras, and of criminals who extract enormous quantities of money and accumulate massive fortunes, fostering precarious work and despoiling the environment. One structural characteristic is the transfer of surplus toward the global core economies by way of payment on external debt, profit repatriation, royalties, inter-firm commerce and capital flight. The oligarchy has been benefitting from privatization and the transfer of public resources; the political class manages the neoliberal project through violence and domination. The economic model is founded upon the extreme plunder of workers' lives and common goods, and the abrogation of worker gains and social rights. In this setting, an economy tied to shaky internal markets and family subsistence persists, but remains stalled and under permanent assault.

KeYwords: capitalism, neoliberalism, State, crisis, Mexico. 


\section{PÓRTICO}

El modelo de desarrollo capitalista neoliberal es un régimen de acumulación orquestado por el Estado para favorecer procesos de valorización insertados en redes globales cuyo cometido es conceder al capital monopolista las fuentes de generación y apropiación de renta y ganancia, sobre todo extraordinaria y de corto plazo. En términos estructurales la economía nacional transfiere sistemáticamente el excedente hacia los centros financieros e industriales de la economía mundial, asimismo aporta recursos naturales y fuerza de trabajo desde actividades volcadas a la exportación a costa de cancelar las posibilidades de organizar ciclos de acumulación y distribución del excedente en la trama nacional y de ampliar el rango de desigualdades sociales. Este proyecto de clase tiene el cometido de concentrar el poder y la riqueza en una delgada élite social articulada como poderoso bloque donde campea una plutocracia compuesta por magnates que dependen de los privilegios otorgados por el Estado, organiza una forma de gobierno oligárquico que genera un consenso de élites en torno al proyecto neoliberal y degenera en corrupción, enriquecimiento y fraude electoral, en tanto que las clases sociales subalternas padecen despojo, pobreza y violencia. La decadencia del sistema de acumulación y poder redunda en crisis del Estado y de las relaciones sociales.

Dentro del tráfago del capitalismo mundial, la mexicana suele presentarse como una de las más grandes y dinámicas, amén de un ejemplo de manejo responsable. En la inserción a los mercados de exportación destaca la participación de los productos maquilados (automóviles, electrónicos y aeroespaciales) y las materias primas (minerales, petróleo y alimentos), sin embargo también repunta la exportación de narcóticos y trabajadores migratorios. A decir verdad, México representa el teatro 
de operaciones del capital monopolista que implementa megaproyectos de corte rentista en las más variadas actividades extractivas, especulativas, maquiladoras y criminales; espacios del capital donde fluyen grandes cantidades de dinero y se acumulan enormes fortunas, pero también se desvaloriza el trabajo y depreda la naturaleza. En esta lógica se afianza la transferencia de excedente hacia los centros de la economía mundial por diversa vías, como el pago de deuda externa, remesas de ganancias, retribución de regalías, beneficios por comercio intrafirma y fuga de capitales. La oligarquía ha sido ampliamente beneficiada por los programas de privatización, transferencia de recursos públicos y otorgamiento de concesiones; en tanto que la clase política gestiona el proyecto neoliberal mediante dispositivos y tecnologías de dominación y violencia, sin reparar en que hunden a las instituciones en la ilegitimidad y pervierten la función pública. El modelo económico tiene soporte en el expolio del fondo de vida obrera, la pauperización del pueblo, el despojo de bienes nacionales y comunales y la abrogación de conquistas laborales y derechos sociales. En ese ámbito aún perviven espacios sociales anclados en el desvencijado mercado interno y la subsistencia familiar que padecen estancamiento crónico y sufren un acoso permanente.

El reinado del modelo de desarrollo capitalista neoliberal sobrepasa las tres décadas en México. El derrocamiento del régimen de acumulación de industrialización por sustitución de importaciones, la clausura del régimen político corporativista y el abandono de la ideología nacionalista revolucionaria fueron los primeros pasos para la implantación del neoliberalismo. El proyecto neoliberal reconfigura el bloque de poder, concentra el capital, inserta el aparato productivo al capital global, reconstruye las relaciones de dominación y promueve una nueva ideología del libre mercado y la democracia electoral.

El modelo neoliberal está sustentado en el expolio de las principales fuente de la riqueza social, la fuerza de trabajo y la naturaleza. En tal sentido promueve la proletarización de la mayoría de la población (la «liberalización» de fuerza de trabajo y la precarización de las condiciones de trabajo) y la explotación superlativa del trabajo vivo (asalariado 
y no asalariado), además del despojo de bienes comunes (tierra, agua, aire, es decir, los elementos vitales arraigados en la biosfera que sirven de sustento inmediato a las comunidades) y bienes de la nación (recursos de suelo, subsuelo y el espacio aéreo que sirven para la infraestructura y comunicaciones, la articulación del mercado interno, la provisión de servicios públicos y la apropiación de una renta de los recursos naturales). La mayor parte de la dinámica económica está volcada a la exportación de materias primas y productos manufacturados en procesos de ensamble, pero de manera sustancial consiste en un régimen de transferencia sistemática de excedentes hacia los centros financieros e industriales de la economía mundial por concepto de ganancias, regalías, patentes, rentas tecnológicas, deuda externa, comercio intrafirma y otros mecanismos de intercambio desigual.

Siendo en apariencia extrovertido y libérrimo, el modelo está profusamente controlado por un tinglado de capitales monopolistas y los principales soportes remiten a comandos externos conectados a la dinámica de valorización en el horizonte internacional que cultivan profundas raíces de dependencia y estrangulan las potencialidades estructurales de un tentativo desarrollo autónomo. Los sectores más dinámicos volcados a la economía mundial recurren a fuentes externas de financiamiento, conocimiento científico-tecnológico, ingeniería, gerencia y mercadotecnia que corresponden a las directrices corporativas de las casas matrices y los recursos e instrumentos de gestión como el ahorro externo, patentes, técnicas de gestión, administración empresarial y diseño de productos están lejos de representar una "ayuda al desarrollo»o "transferencia del progreso tecnológico». Pese al tono fúnebre de sus enterradores, los Estados nacionales juegan un papel relevante para apuntalar y subsidiar al capital corporativo (créditos, infraestructura, becas, exenciones), y la sacrosanta política macroeconómica (contención de la inflación, represión salarial, "autonomía» de la banca central, precarización laboral, control político de sindicatos) favorecen abiertamente a los intereses del capital monopolista. 


\section{HEGEMONÍA SIN CONSENSO}

En la etapa posrevolucionaria, por más de siete décadas se extiende en México la hegemonía del régimen autoritario presidencialista: el jefe del Ejecutivo era la encarnación del poder con facultades constitucionales y metaconstitucionales que le permitían controlar a los otros poderes formales, el sistema de partidos y los procesos electorales (Carpizo, 2006). Este régimen vivirá su esplendor de 1935 a 1988. No obstante, diversas revueltas sociales y frentes electorales harían mella en el régimen político: el movimiento estudiantil de 1968 sofocado con una matanza, la coalición de centro-izquierda en 1988 contenido con el fraude y la irrupción del Ejército Zapatista de Liberación Nacional (EZLN) en 1994 cercado militarmente. El sistema político abrirá una válvula de escape con sucesivas reformas electorales desde 1977 hasta la supuesta «transición democrática» que permitirá a políticos aliados de la derecha y centro-izquierda acceder paulatinamente a gubernaturas, senadurías, diputaciones y presidencias municipales, con lo cual se logra desmovilizar a amplios sectores sociales. No obstante, serían las élites políticas quienes darán el golpe de timón al derrocar el proyecto desarrollista, la ideología nacional-revolucionaria y el populismo, no para transitar hacia la democracia sino para entregarse al Consenso de Washington que prescribe el modelo neoliberal y se va instrumentando con el Acuerdo General sobre Aranceles Aduaneros y Comercio (GAтt, hoy Organización Mundial del Comercio [омс]), el Tratado de Libre Comercio de América del Norte (TLCAN), entre otros mecanismos. Para enaltecer el discurso de «ingreso al primer mundo» se maquilla al régimen político con organismos supuestamente autónomos en materia electoral (Instituto Federal Electoral [IFE], hoy Instituto Nacional Electoral [INE]) y derechos humanos (Comisión Nacional de Derechos Humanos [CNDH]). La «transición a la democracia» cristalizada con el arribo de la derecha panista a la presidencia de la República terminó por ser un mero acto soberano de la élite del poder que reduce la alternancia sólo a políticos de confianza fuertemente coaligados al proyecto neoliberal, pero al final de cuentas la alternancia de dos sexenios expira con el 
retorno del Partido Revolucionario Institucional (PRI). La vía electoral no deja de ser una representación fársica del avance democrático.

El sistema de partidos estará comandado por el partido de Estado cuya columna vertebral es el sempiterno PRI-gobierno y la corte de partidos satélites, que una y otra vez renovaran sus siglas y discursos, pero no la intención de fungir como comparsa (López Villafañe, 1986).

Desde el proceso inicial de formación del poder político en el México posrevolucionario, el Ejército fue una columna vertebral. En los años veinte del siglo pasado se va fraguando el aparato postrevolucionario hasta institucionalizarse la Revolución, pero a costa de represiones y matanzas. La "gran familia revolucionaria» se reparte el poder y a ese acto supremo se le denomina «justicia revolucionaria». El Ejército siempre ha sido un aparato militar con un papel volcado "hacia adentro" que le ha permitido al poder político imponerse y reprimir a la sociedad; nunca ha sido un Ejército con funciones reales "hacia fuera» como la defensa de la soberanía nacional o la intervención en conflicto bélicos externos, pero no por ello es una fuerza pacifista, al menos en el plano interno. Ahora es un instrumento de la llamada "guerra contra el narcotráfico» y la represión social, por tanto es un fiel guardián del modelo neoliberal y el régimen político concomitante (Márquez, 2015).

La cultura política mexicana ha estado fuertemente imbricada en la dupla corrupción-impunidad que permite a los jefes de la clases política y a la alta burocracia preservar acuerdos y ejecutar reformas neoliberales de manera que se puedan conciliar los intereses de las grandes corporaciones del capital privado y los propios de la clase política que en este estatus percibe altas remuneraciones, privilegios y canonjías. La noción de corrupción no sólo implica formas de enriquecimiento ilícito, tráfico de influencia, soborno, asignación preferencial de partidas presupuestales, adjudicación de obras, lavado de dinero y colusión con la criminalidad, sino que también entraña la perversión del sentido mínimo del acontecer democrático pues la política es fetichizada (Dussel, 2006) y en lugar de que el cargo público se ejerza representando a los diversos sectores sociales e intereses nacionales y obedeciendo las reivindicaciones 
e intereses de grupos, sectores y clases sociales, en un acto de prestidigitación los funcionarios se separan de la representación efectiva y terminan, primero, por representarse a sí mismo y, luego, fungen como activos y entusiastas gestores de los grandes capitales, los cuales, a su vez, son presentados a la sociedad como los auténticos agentes del desarrollo merced a su capacidad de inversión, generación de empleo y bienestar, bajo los preceptos de una irresoluta teoría del goteo. Mientras tanto, la clase política potentada abre y consolida los espacios de poder bajo un esquema institucional que le permite repartir puestos, reciclar personajes políticos y tejer acuerdos palaciegos en consonancia con cabilderos, expertos y demás personeros de los grandes capitales.

\section{Un peor gobierno, imposible}

Luego del breve lapso de dos sexenios presidenciales panistas, que fueron presentados como si fuesen la «transición a la democracia», fue restaurado el vetusto régimen priista sin que ello signifique una mera vuelta al pasado donde, parafraseando a Monterroso (1969): «cuando [el país] despertó [después de una alternancia de pesadilla], el dinosaurio [priista] todavía estaba ahí», en el poder. En realidad significa algo más: la continuación y profundización del proyecto neoliberal que comienza en los ochentas y continúa con los gobiernos de la derecha conservadora panista durante dos sexenios presidenciales. También significa la reconcentración del poder político que gestiona nuevos espacios de valorización para el gran capital activando instancias de gestión parlamentarias y extraparlamentarias que conforman una especie de partido del gran capital, donde se anudan las siglas de la mayoría, sino es que de todos los partidos políticos, y los poderes fácticos. Por ello la tecnocracia neoliberal prohijada en los sexenios anteriores toma las riendas de las altas esferas de la burocracia política para implementar con celeridad el tercer ciclo de reformas neoliberales con la urgencia de hacerlo rápido, sin dar tiempo a la resistencia ciudadana. 
Sin embargo, la crisis de legitimidad marca todo el ciclo de reformas neoliberales y la clase política se empantana en un enorme descrédito público que torna insufrible el bajo perfil de la clase dirigente inmersa en la frivolidad, el enriquecimiento y la corrupción. Un término evocador del resquebrajamiento estatal y el gobierno diletante es kakistocracia, que significa: "La combinación de la tiranía, la oligarquía y la demagogia: el pésimo gobierno, la república de los peores» (Bovero, 2003). El gobierno se ejerce sobrepasando a los otros poderes, eludiendo la consulta popular para promover los intereses de los poderes fácticos, desterrando los derechos sociales y emitiendo un discurso dirigente desde los medios electrónicos con mensajes irrelevantes o chabacanos que encubren los grandes problemas nacionales. El marco institucional genera políticas públicas que no corresponden a las necesidades sociales ni a un proyecto de desarrollo nacional: la pauta del despojo y la exclusión marcan el paso de la reproducción social. El rasero de la mediocridad recorta a las élites políticas y deteriora a las instituciones; la órbita estatal es penetrada por conglomerados criminales. Los signos de la kakistocracia en México son diversos.

Las élites políticas se enriquecen frenéticamente en un país con la mayoría de las clases sociales sumidas en la pobreza. En contrasentido a la deteriorada estructura económica, la falta de probidad en la función pública y el escaso compromiso social de la alta burocracia, las élites gubernamentales, parlamentarias y judiciales perciben salarios excesivamente altos. Mientras que un salario mínimo anual ronda la modesta cantidad de 255 mil 865 pesos, insuficiente para afrontar el costo de la vida, los magistrados de la Suprema Corte de Justicia de la Nación detentan ingresos exorbitantes de 6 millones 766 mil 428 pesos anuales; el presidente de la República, 2 millones 989 mil 128 pesos; los senadores, un millón 925 mil 945 pesos, y los diputados, un millón 432 mil 997 pesos (Garduño, Méndez y González, 2015). La desproporcionada estructura salarial entre la alta burocracia y la clase trabajadora es uno de los puntos de comparación de la desigualdad social del país. Pero no sólo los sueldos de la élite política mexicana están 
disparados frente al sueldo medio de los mexicanos sino que tampoco tienen punto de comparación lógica con las percepciones de sus pares en Estados Unidos, Europa y América Latina.

El gobierno adquiere el rostro oligárquico. Los tres poderes responden a intereses exclusivos: el Poder Judicial actúa como una oligarquía que refrenda los intereses del capital y la élite política; el Poder Legislativo funge como una oclocracia populista que adopta posturas acordes a los intereses electoral, pero en las grandes decisiones toma acuerdos tras bambalinas, sin consulta popular, como el llamado Pacto por México, que reduce al legislativo a una suerte de oficialía de partes del Ejecutivo y de las elites partidistas, además de que los grandes corporaciones y poderes fácticos, incluyendo el narcotráfico, tienen representantes directos o logran imponer sus intereses mediante los servicios de cabilderos; y el Poder Ejecutivo adopta aires de tiranía pues avasalla al poder Legislativo, que sólo avala decisiones previamente tomadas, como en el referido Pacto.

Los gobernadores ejercen un papel subordinado al Ejecutivo, aplican las determinaciones del poder político centralizado, pero también aplican formas del presidencialismo autoritario. Instancias como la Conferencia Nacional de Gobernadores (Conago) fueron allanando el camino para las sucesivas reformas neoliberales y la adopción de la doctrina de la seguridad como una forma de gestión social mediante directrices punitivas y coercitivas.

Las autoridades municipales y policiales de todos los niveles, en gran parte del país, están coludidas con el crimen organizado. La desaparición forzada de 43 normalistas y el asesinato de 6 personas, entre ellas tres normalistas, exhibió la grave corrupción de las autoridades y las corporaciones policiacas, en una espiral de complicidad que asciende hacia arriba en las líneas de mando y ámbitos de gobierno. En ese contexto truculento los comicios se han enturbiado y la lucha antimafia en México está lejos de significar una política de Estado frente a la expansión del narco.

La derechización del espectro político y el descarrilamiento fáctico de la opción opositora de corte nacionalista moderada, además de ge- 
nerar una desencanto popular sobre los procesos democráticos, permitió que el Pri, el Partido Acciona Nacional (pAN) y el Partido de la Revolución Democrática (PRD), incluyendo a los partidos pequeños que juegan el papel de comparsa, signaran el «Pacto por México» donde, sin resquemores, se emprende el tercer ciclo de reformas neoliberales, que incluye la cesión al capital privado multinacional y nacional del petróleo con el desmantelamiento de Pemex y el endoso de la renta petrolera; la reforma laboral que abarata aún más la fuerza de trabajo y legaliza la inseguridad contractual con el despido libre, pago por horas y subcontratación; la reforma educativa que no contiene un proyecto de mejora sustancial de la educación pública, el sistema pedagógico, la infraestructura escolar, la nutrición y salud de los educandos, mejores condiciones salariales de los educadores, democratización del sindicato, etcétera, sino que impone esquemas punitivos de evaluación y amenaza de despido bajo las indicaciones de la Organización para la Cooperación y el Desarrollo Económicos [OCDE] y el grupo de interés empresarial Mexicanos Primero, entre otras reformas.

No obstante que aplican lesivas medidas de austeridad, los gobiernos suelen caracterizarse por derrochar recursos en obras suntuarias o actividades irrelevantes, aumentar los impuestos y endeudarse. En tanto la opacidad y ausencia de consulta ciudadana marcan la tónica, los marcos normativos se eluden para propiciar el enriquecimiento a costillas del erario. Pese a las reiteradas muestras de corrupción de los funcionarios públicos y la clase política, el sistema electoral juega un papel que da sustento a los grupos políticos que ensanchan los espacios de poder y sus personeros siempre están en la palestra y los puestos clave. Sin recato alguno los políticos incumplen las promesas de campaña, pues saben que mentir o traicionar la voluntad popular no tiene ninguna consecuencia. Como tampoco lo tiene ejercer la función pública sin transparencia y hacer negocios con empresarios afines mezclando recursos públicos y privados. El ejercicio prepotente del poder se solaza al fustigar las manifestaciones ciudadanas y señalar a líderes opositores como agentes desestabilizadores del país, además de incurrir en excesos 
como represión encarcelamiento o matanza. Desde la cúspide, sin hacer la menor autocrítica, con cinismo se califica a la corrupción y la violencia como un asunto cultural (Rodríguez, 2014).

La procuración de justicia está picada por la falta de garantías, los derechos humanos atraviesan por una crisis generalizada y los procesos judiciales están cuestionados, por ejemplo, la aplicación selectiva del principio de presunción de inocencia. La administración de la justicia está politizada y a menudo los casos se dirimen en los medios de comunicación, lo cual induce sesgos en la opinión pública y permite que los potentados filtren información a conveniencia. Infinidad de casos saltan a la escena sin que se resuelvan, como la guardería ABC, los mineros de Pasta de Conchos, las fugas del Chapo Guzmán, la masacre de 72 migrantes, los 43 estudiantes desaparecidos, y un largo etcétera. Los comunicadores y columnistas de opinión, los gobiernos y políticos se atacan usando los expedientes judiciales para evitar el mayor costo electoral u obtener ventajas políticas. No obstante, los procedimientos judiciales se entorpecen y los casos quedan sepultados en la impunidad. En ocasiones la presión mediática y social orilla a que se realicen detenciones, pero suelen caer empleados de bajo perfil, el eslabón más débil de la burocracia, incluso se fabrican falsos culpables. En algunos casos se «arraigan» a determinados personajes influyentes, que pueden eludir las responsabilidades, mientras que en la cárcel de alta seguridad están presos que se oponen o resisten a la política de despojo y en esos casos las pruebas aportadas son endebles, como puede ser simplemente el testimonio de policías.

Los gobernantes, la alta burocracia y el conjunto de la función pública, al igual que los partidos políticos, las instituciones electorales y los procesos comiciales adolecen de falta de ética política. Las altas remuneraciones de las élites políticas son un incentivo perverso de los procesos electorales, que por ello son muy disputados, y no porque se pongan a debate proyectos de desarrollo nacional. Al seno de los partidos políticos y al calor de las contiendas electorales se despliegan confrontaciones agresivas que se valen de "guerra sucia»y onerosos 
gastos de marketing con tal de agenciarse una candidatura y un puesto de representación sabedores de que el erario es un trofeo muy apetitoso y que el espacio de la función pública es la arena privilegiada donde se tejen negocios con empresarios, pactan con el crimen organizado y obtienen recursos para cubrir jugosas prestaciones, gastos personales y viajes familiares. La función pública se pervierte para convertirse en un botín para los sátrapas.

La compraventa y coacción del voto de forma masiva ha sido uno de los métodos más socorridos por los partidos para disputarse y preservar los puestos de representación y los espacios de poder político (p.ej., los recientes casos de Soriana-Monex). Las instituciones electorales amasan y destinan grandes cantidades de dinero para promover a figurines políticos en una operación donde trasladan fuertes montos de dinero público a las empresas privadas de la comunicación y al mismo tiempo se involucran entradas de cuantiosos fondos no declarados provenientes de patrocinadores empresariales y del hampa; en esa feria de liquidez electoral los gobiernos y los partidos se complacen repartiendo dádivas a la población menesterosa que por hambre o necesidad emite un voto condicionado favorable a los partidos que manejan mayores recursos lícitos e ilícitos. En conjunto, las elecciones son una simulación democrática y un ejercicio perverso de mercantilización del voto.

El duopolio televisivo, por muchas décadas formador de la conciencia colectiva, ejerce un activismo político crucial para los juegos del poder. En México campean los peores medios de comunicación posibles. El duopolio mediático de Televisa y TV Azteca destaca por la mediocre programación audiovisual que irradia en la conciencia colectiva de millones de espectadores sin otra fuente de información y entretenimiento más que las pantallas de la televisión comercial. Es conocido que Televisa pactó una alianza con Enrique Peña Nieto para convertirlo en el candidato presidencial ganador (Solís y Acos ta, 2015). Pero también que TV Azteca implementa campañas de desprestigio o veto a políticos opuestos a los intereses del grupo 
Salinas. La amoralidad política es tolerada por los medios masivos de comunicación que la encubren e influyen en amplias capas de la sociedad para encubrir las trapacerías.

\section{Galardón a los alegres compadres}

Con el modelo neoliberal el gobierno en México está fuertemente influido por los multimillonarios, pero el gobierno a su vez soporta la riqueza de los magnates. La plutocracia es una relación simbiótica entre los poderes político y económico.

La imposición del modelo neoliberal no sólo transforma la estructura económica para consolidar el dominio de los capitales monopólicos sino que además recompone la estructura de clases sociales, que en ambos polos de la relación vincula a dominantes y subordinados. Sobre todo reconstruye el bloque de poder y su fracción hegemónica. A finales de los sesenta, en la antesala del neoliberalismo prevalecía una pequeña oligarquía financiera que representaba la fracción hegemónica del bloque en el poder, debido a la concentración y centralización de capital y a la transnacionalización de la economía al cierre de la industrialización por sustitución de importaciones. Un millar de familias concentraba el poder económico que les permitía incidir al seno del Estado e influir en la definición de la política (Carmona, Montaño, Carrión y Aguilar, 1970).

La composición de la clase dominante fue restaurada al influjo del modelo neoliberal. En el ámbito político, con el llamado Consenso de Washington (el pacto del capital financiero y los Estados nacionales) conformó una alianza entre el capital monopolista-financiero de los centros y las élites nacionales de las periferias, con el objeto de desplegar el poder del capital multinacional financiero, industrial y comercial, alentados por el proyecto de la llamada globalización. Algunas de las grandes corporaciones que en los ochenta actuaban en el mercado interno reconvirtieron sus empresas para orientarlas hacia la nueva fuerza gravitacional de la economía: el mercado externo (Guillén, 2012). 
Entonces nuevos fracciones tomaron lugar en la oligarquía y ocuparon el pedestal en la cúspide del poder.

El proyecto neoliberal está sustentado en una férrea estructura de poder: a) los dueños de los grandes grupos monopólicos de base multinacional y nacional que controlan los sectores económicos estratégicos y rentables, gran parte de los cuales han sido cedidos por el Estado, y para perdurar dependen de los privilegios y recursos transferidos por los poderes públicos; $b$ ) los tecnócrata, la alta burocracia, los jefes de la clase política, los líderes de la centrales sindicales oficialistas; c) los propietarios de los medios masivos de comunicación de la televisión, la radio y los grandes diarios nacionales y regionales, y con ellos los «líderes de opinión " y los intelectuales orgánicos; d) los altos altos jerarcas eclesiales; e) los altos mandos castrenses y de las fuerzas del orden, y $f$ ) en el peculiar narcocapitalismo mexicano también figuran los grandes capos del narcotráfico junto a la "narcoburguesía» que opera en los más variados sectores económicos legales e ilegales.

El programa de privatización de empresas estatales y paraestatales implementado por la desmesurada administración de Carlos Salinas armó el rompecabezas del tablero oligárquico incorporando una camada de nuevos ricos, a menudo sin experiencia empresarial, en sectores clave de la economía nacional: banca, telecomunicaciones, medios de comunicación, entre otros. Un rosario de magnates son los grandes beneficiarios del régimen político y forman el «capitalismo de los compadres»: Carlos Slim (Grupo Carso), Roberto Hernández (Banamex), Alfredo Harp Helú (Banamex), Ricardo Salinas Pliego (Televisión Azteca), German Larrea (Minera México), González Barrera (Gruma, Banorte), Alberto Bailléres (Grupo Bal), entre otros (Forbes, 16 de diciembre de 2013). Los selectos hombres de negocios deben más su fortuna a los privilegios y concesiones otorgados por el Estado que a la presunta capacidad empresarial e innovadora. Incluso la subsistencia de sus corporaciones dependerá, en lo sucesivo, del poder monopólico tutelado por el Estado, y a la serie de concesiones, favores fiscales, transferencias de recursos públicos y rescates en caso de bancarrota, además del control sindical. 
La connivencia político-empresarial ha tomado tintes escabrosos al condecorar con la medalla Belisario Domínguez a Alberto Bailléres, propietario de Peñoles, el Palacio de Hierro, Femsa-Coca-cola, seguros GN P e ITAM, en reconocimiento a su contribución a la generación de empleos, la enseñanza y la filantropía, sin mencionar las generosas donaciones a las campañas políticas del oficialismo (Martínez, 11 de noviembre de 2015). Cabe recordar que Belisario Domínguez fue un senador chiapaneco, opositor al usurpador Victoriano Huerta, que fuera asesinado por sus críticas pronunciadas en el Senado, y en su memoria la medalla que lleva su nombre es «la más alta condecoración otorgada a los ciudadanos más eminentes», aunque no siempre haya sido así, y en el caso del magnate bien pudieran cambiar la nombradía de la medalla para ponerla más a tono con los nuevos atributos de los prohombres del sistema.

\section{Cría de monopolios}

En el Banco Mundial, gran impulsor de las privatizaciones, se reconoce que un reducido grupo de 20 personas o familias de México concentra la riqueza al detentar mil millones de dólares entre 1996 y 2006 y controla la producción de sectores como minería, banca, telecomunicaciones, cerveza, cemento, industria farmacéutica, comercio al menudeo, bienes raíz, televisión y tortillas (Guerrero, López y Walton, 2006). Para explicar el origen de las fortunas el Banco suponía que la mayoría de los magnates la heredó en parte pero también reconocía que casi la mitad había sido beneficiada por las privatizaciones de principios de los años noventa.

En estos sectores operan monopolios u oligopolios que controlan hilos clave de la economía y la cultura nacionales. Dos grupos, Televisa y Tv Azteca, controlan la televisión abierta; dos grupos, Modelo y Cuauhtémoc, controlan la producción de cerveza (aunque ya fueron vendidos a multinacionales), algo similar sucede en la industria refresquera (Femsa), la telefonía (Telmex), el sector minero (Grupo México, Peñoles, Frisco) y la industria del cemento (Cemex). 
Un acceso preferente en materia de inversión está reservado a las multinacionales que además reciben trato como si fuesen entidades nacionales o, más aún, disponen de la libertad para repatriar utilidades. En el marco del trCan, los supuestos "socios comerciales» de México, las corporaciones estadounidenses y canadienses son las más favorecidas al exentar la reinversión de utilidades, eludir la contratación de un cierto porcentaje de trabajadores mexicanos y omitir el uso de insumos nacionales, entre otros aspectos. Las multinacionales expanden su presencia mediante las fusiones y adquisiciones, estrategia que les permite reemplazar el componente de inversión nacional por extranjera hasta engullir capitales y apropiarse de sectores económicos completos.

En el sector financiero cinco grupos, la mayoría extranjeros (Banamex-Citigrup, BBvA-Bancomer, Santander, HsBC y Banorte), dominan la intermediación en actividades bancarias, aseguradoras, fianzas e intermediación financiera no bancaria (Turrent, 2007). De esta manera, los cinco principales bancos participaron con 77.2 por ciento de los activos totales en 2009 , porcentaje que se redujo a 73.6 por ciento en 2010, pero que es igual al de 2001; aún mayor es la concentración en el sector de la intermediación financiera no bancaria, en el que los activos de las cinco principales Sociedades Financieras de Objeto Limitado (SOFOL) representaron en 2009 a 88.4 por ciento de los activos de esas instituciones (Auditoría Superior de la Federación, 2011).

Gracias al programa de privatización a bajo costo de empresas estatales pudo reconfigurarse la oligarquía nacional que ha "capturado» el poder político y debilitado la democracia representativa a través de un proceso marcado por la corrupción, la represión y la violencia. En sintonía con la ideología neoliberal, los medios de comunicación promueven el individualismo y el consumismo, además de que establecen una diferenciación entre personas "ganadoras» $y$ "perdedoras», según la riqueza personal que ostenten y el poder que detenten.

La oligarquía es dominante "hacia adentro» pero está subordinada "hacia fuera». De manera ascendente, el Estado y la oligarquía mexicanos se están subordinando a los intereses estadounidenses. El rentismo 
es el signo oligárquico en el contexto de una dinámica de acumulación de capital que tiende a debilitarse y a transferir excedentes hacia las economías centrales. En tanto que el Estado, que había mantenido cierta autonomía antes del advenimiento del neoliberalismo, aceptó entregarse al poder hegemónico representado por Washington desde la firma del trcan y la subordinación continúo con el Acuerdo de Seguridad y Prosperidad de América del Norte (ASpan), ahora Iniciativa Mérida. Esa política no sólo ha servido para respaldar la articulación del bloque económico de América del Norte sino que también forma un espacio para definir políticas en materia de seguridad regional a partir de los intereses globales de Estados Unidos. Derivado de la doctrina de seguridad, la Iniciativa Mérida estipula una lucha contra los "enemigos externos», según la lente estadounidense, sean terroristas o narcotraficantes; además contempla detener el flujo migratorio que proviene de Centroamérica y México con destino a Estados Unidos, y en ese cometido al gobierno mexicano asume la responsabilidad de contener la avalancha humana en su territorio con la implementación del programa Frontera Sur, subsidiario de la Iniciativa Mérida.

\section{La muerte tiene permiso}

La desmesura del poder estatal opresivo y represivo ha sido definida como fascismo, donde la lógica de la muerte se justifica para preservar el régimen. Más allá de esas truculentas experiencias, el capitalismo neoliberal practica una forma de poder que puede catalogarse como gestión de la muerte. Esta política está enmarcada en la expansión del capital global y en esa lógica la vida se produce suponiendo que es un recurso desechable.

El fantasma del fascismo no habita en los regímenes políticos autoritarios del pasado sino que ésta presente de muchas formas en la política contemporánea, en particular en la que tiene como eje la administración de la muerte (Chávez, 2013). La noción de lo político alcanza notas tétricas acordes a los tambores de la guerra y la atmósfera del 
terror. La voluntad de poder que, además de disponer de la capacidad soberana para determinar quién vive y quién muere, se arroga el derecho de organizar el homicidio y recrear la muerte como fenómeno social es nombrada necropolitica (Mbembe, 2012). Desde esa tesitura, la gestión de la muerte no necesariamente remite a las experiencias totalitarias del holocausto europeo, sino que alude a la experiencia histórica del colonialismo africano y americano y a la formación neocolonial del capitalismo contemporáneo, junto a la propagación de conflictos bélicos por fuerzas aliadas imperialistas.

Luego de la caída del muro de Berlín y el derrumbe de la Unión Soviética, el capitalismo triunfante promulgó el «fin de la historia» y el "fin de lo político», porque supuestamente se agotó la expectativa de una sociedad poscapitalista y porque se diluyó el antagonismo social bajo una ilusoria era posmoderna que disolvía las grandes narrativas y los conflictos entre capitalismo y comunismo. Entonces el terreno de la política sería para la construcción del consenso de Washington y el Estado asumiría la administración del bienestar y la multiculturalidad. El sueño quedó hecho añicos luego de los ataques a las Torres Gemelas de Nueva York en 2001. Entonces se difunde el discurso del choque de civilizaciones (Huntington, 1993), una confrontación maniquea entre las culturas de Occidente y Oriente que sirve de pretexto para replantear una soberanía desde la cual el estado de excepción permanezca latente ante los temores suscitados por el antagonismo amigo-enemigo.

Al fragor del llamado "nuevo imperialismo» (Harvey, 2004), el discurso político adquirió pretensiones civilizatorias según las nociones de libertad y democracia para justificar la guerra y el terror, y en ese impulso expandir los espacios de acumulación del capital excedente de las grandes potencias. La política supera los discursos apocalípticos de las décadas precedentes para invocar el recurso de la violencia estatal como dispositivo legítimo de la supremacía occidental. Las ocupaciones e intervenciones militares - Irak y Afganistán- eran justificadas más allá de las convenciones internacionales. Un punto de inflexión es la política impuesta por Estados Unidos y sus aliados luego de los 
atentados del 11 de septiembre con la aplicación de la "guerra contra el terrorismo", que posibilitaría un relanzamiento de la política imperial con ocupación militares de territorios lejanos, sobre todo del mundo no occidental, la difusión de tácticas de contrainsurgencia. La llamada globalización neoliberal está preñada de una violencia que privatiza la esfera pública, fortalece al Estado y el capital global comanda las transformaciones económicas y políticas.

El paisaje social está plagado de escenas de desgarramiento del tejido social que se enmarcan en una estética decadente: la poética de la violencia. Los espectros de la violencia generan confusión y diluyen la distinción entre suicidio y rebeldía, sacrificio y redención, martirio y libertad. Los vocablos de la vida cotidiana pronuncian las escenas y personajes del terror: sicario, desaparición forzada, feminicidio, falsos positivos, levantones, daños colaterales. El desgarramiento del tejido social irrumpe como la forma de socialización que inhibe la organización y el movimiento social.

La administración de la muerte pervive en un estado de excepción que tiende a normalizarse en el seno del modelo político neoliberal, aunque no es un rasgo nuevo pues está enraizado en la genealogía del colonialismo histórico, donde la producción de vidas desechables, como los esclavos de las plantaciones o los pueblos originarios ocupantes de territorios sujetos a explotación, en el capitalismo contemporáneo sigue siendo una norma de la expansión del capital.

Cuando en aras de maximizar las ganancias y las rentas, la vida humana se instrumentaliza hasta reducirla a una mercancía barata y desechable, una mercancía que produce mercancías, o, peor aún, la corporalidad viviente es atacada y ciertos conjuntos humanos son considerados como superfluos, la normalidad capitalista adopta el estado de excepción para darle carta de naturalización o al menos para dejar de considerarlo como ajeno. La imposición de un estado permanente de guerra es un cometido del poder que se vale de un discurso ideológico obsesivo que identifica peligros externos e internos para la seguridad y en consecuencia identifica enemigos -llámese 
terroristas, narcotraficantes o inmigrantes - que ameritan ser atacados con virulencia si se quiere mantener a buen resguardo los sacrosantos principios de la democracia burguesa y la libertad del capital. El discurso apologético justifica la excepción con la mención del enemigo y el terror, y enarbola la guerra en pos de la democracia y el libre mercado. En la política contemporánea se articulan la violencia y el derecho, la excepción y la soberanía.

La expansión del capital es una cuestión determinante en la gestión política de la muerte que legitima la noción de vida desechable. El discurso de la modernización y el progreso justifica los actos legales e ilegales de expropiación del territorio y la explotación de la población. La empresa colonia en la era del capital global configura espacios donde se impone una lógica de guerra y un discurso de la competitividad. La ocupación de territorios para extraer los recursos naturales y explotar el trabajo emplea métodos violentos que se concretan en la figura de la economía de enclave, que se remite a la plantación. Los pueblos son despojados de bienes comunes, bienes públicos y derechos sociales (Roux, 2012). Este despojo se traduce en una subsunción real del capital sobre la reproducción social que aliena la reproducción de la vida humana desde el nacimiento hasta la muerte social. La economía de enclave es una estructura económico-política donde el sujeto despojado carece de medios de vida y trabajo y el capital organiza una forma sistemática de transferencia del excedente.

La expansión del capital global reedita el expediente colonial y continúa implementando la violencia. En el espacio colonial contemporáneo se ejerce una soberanía donde lo ilegal se convierte en norma y la paz adquiere el rostro de la guerra. El capital despoja, cerca, ocupa, acapara y controla los territorios, incluyendo sus recursos naturales y humanos. El ejercicio de la soberanía mediante la guerra y la conquista tiene la capacidad de tasar a los sujetos y designar aquellas vidas que considera como desechables. La guerra y la excepción soportan la ocupación colonial que produce una forma de hacer política que permite el control de los territorios para extraer los recursos naturales y explotar el trabajo 
dentro de ciclos productivos globalizados donde se sustrae y transfiere el excedente económico y las energías vitales de la población hasta generar un clima socioambiental de degradación que sólo es regulado mediante la administración de la muerte.

La dinámica de acumulación capitalista sigue sacándole jugo a la ideología nacionalista. El Estado nación es un agente central del gran capital, como lo era en las antiguas colonias, para justificar la conquista territorial como modo de aniquilamiento, pese a que este poder no sea exclusivo y actúe en sintonía con otras instancias y dispositivos que sobrepasan la estructura del Estado nación, tales como las corporaciones internacionales o el narcotráfico.

El capitalismo neoliberal despliega una violencia que busca una legitimación más allá de la noción del «monopolio de la violencia» por el Estado y recurre a las nociones de guerra, soberanía y enemigo, además de a una serie de mecanismos articulados para generar el terror a fin de controlar y explotar recursos estratégicos en diversas partes del orbe.

La estructura de poder que genera una violencia extrema está inscrita en la lógica del capitalismo contemporáneo y avanza por espacios ampliados de excepción que tienen a normalizarse y organizarse por temporalidades regidas por el signo de la muerte y tornan inviable la noción de futuro o sustentabilidad. En esa lógica se han impuesto políticas de seguridad apuntaladas con nuevos dispositivos tecnológicos que permiten ejecutar ataques con aviones no tripulados, realizar acciones de espionaje a gobiernos y personas, decretar normas antiterroristas, ampliar la infraestructura carcelaria, deportar a migrantes, instalar campos de refugiados y otras formas de excepción insertas en el ámbito legal (Chávez, 2014). El derecho de matar está implícito en esta lógica política que dice procurar la paz y el orden al tiempo que confiere una impronta de vida desechable a las personas ubicadas en las clases sociales subalternas.

La condición de excepción queda asentada como norma en México. El Estado funge como una máquina de guerra orientada a garantizar la explotación de recursos y el control de la población. Con la profundi- 
zación del neoliberalismo, el espectro de la violencia adquiere mayor complejidad. El deterioro estatal toma señales de identidad en la corrupción, la opacidad, el fraude electoral, el nepotismo, el enriquecimiento y el favorecimiento a los monopolios; además de que aumenta la economía criminal, cuyo radio de acción determina que grandes regiones del país se reduzcan a territorios sometidos a la administración de la guerra o la necropolítica.

La economía criminal está anclada en la política como forma socioeconómica gestionada por el Estado desde la política prohibicionis ta y el control de rutas de trasiego como por la adopción de la política de "guerra contra las drogas» donde se señala un enemigo de la seguridad pública, los narcotraficantes, para justificar y legitimar formas ampliadas de control y represión del Estado, que permitan expropiar territorios para la explotación de recursos naturales y mantener el régimen de acumulación y poder. En el escenario entran en juego diversos agentes estatales, paraestatales y sociales que se confunden: militares, policías, narcotraficantes, paramilitares o autodefensas. La guerra y el terror son empleados para impulsar un populismo punitivo y legitimar el estado de excepción donde el derecho de matar toma carta de naturalización y la población más vulnerable carece de elementos de defensa. En los códigos de la política de seguridad, distintos segmentos de la población pueden ser catalogados como víctimas, daños colaterales, falsos positivos, transgresores de la ley, anarquistas, manifestantes, revoltosos, violentos, malosos...

\section{CAPITALIZACIÓN A CONTRAPELO}

La implantación del modelo neoliberal implicó una «acumulación por despojo» (a la manera de Harvey, 2007), es decir, la expropiación de la riqueza nacional y los bienes comunes, el expolio del fondo de vida de la población y la abrogación de los derechos sociales. Las grandes empresas multinacionales son a la vez impulsoras y beneficiarias de la masiva desposesión 
gestionada por los gobiernos nacionales y organismos financieros internacionales. Algunos de las formas de gestión del despojo y la transferencia de la riqueza impuestas por los gobiernos neoliberales se desglosan a continuación.

\section{Inmolación del trabajo vivo}

Desvalorizar la fuerza de trabajo es una política deliberada del Estado mexicano para abaratar los costos laborales que se ha traducido en una agobiante represión salarial y el sometimiento del aparato de justicia laboral al Poder Ejecutivo, además de detonar conflictos laborales sin resolverlos deliberadamente, como ocurrió con el Sindicato Mexicano de Electricistas (SME), los mineros y los trabajadores de Mexicana de Aviación. No se ha cumplido la transparencia sindical invocada en las recientes reformas laborales, pues se prefiere preservar el esquema sindical regresivo basado en cotos de poder sindical y miles de contratos de protección patronal.

Desde 2008, México presenta costos laborales equiparables a China, el referente mundial del trabajo barato (Proméxico, s.f. ), y desde 2013 ostenta menores niveles salariales. Según el Bank of America Merrill Lynch, el salario por hora en el sector manufacturero mexicano hace 11 años era de casi el triple que el chino, pero con la reciente reforma laboral, un trabajador mexicano en abril del 2013 representaba un costo 20 por ciento menor que el de un chino (Reuters, 2013). De acuerdo con la retórica neoliberal, la reforma laboral contribuiría a generar empleos, aumentar la capacidad adquisitiva y mejorar las condiciones laborales; como era de esperarse, no se ha cumplido.

Con la confiscación del fondo de vida de la población, las corporaciones multinacionales encuentran nuevas formas de sustracción de riqueza. Los salarios sufren un desplome permanente y las condiciones de trabajo se precarizan. A costa del empobrecimiento estructural de los trabajadores los capitalistas obtienen jugosas ganancias extraordinarias. 
Durante la vigencia del neoliberalismo el poder adquisitivo del salario mínimo se ha deteriorado aceleradamente. Desde 1987 a 2014 la pérdida del poder adquisitivo del salario es de 78.66\% (сAм, 2014a). La economía popular ha sido duramente golpeada y México se ha tornado una «fábrica de pobres» (САM, 2014b). Con el salario mínimo, una familia sólo puede adquirir 34 por ciento de una canasta básica formada por apenas 40 productos alimentarios básicos. Independientemente de que los precios de esa canasta varían en los supermercados (195.30 pesos), mercados públicos (186.3 pesos) y tianguis (172.4 pesos). Mediante el salario mínimo de 67.29 pesos, el poder adquisitivo equivalía sólo a 63.25 por ciento de la canasta alimentaria básica en 2006 y a 77.79 por ciento en 2014. En 1987 sólo se requería laborar cuatro horas con 53 minutos, es decir, menos de una jornada de trabajo completa para adquirir los alimentos de dicha canasta y para 2012 se requerían 25 horas con 21 minutos para obtenerla.

Por añadidura, a fin de privatizar de forma directa las pensiones e indirecta sectores como la educación, vivienda, cultura y la salud, está en curso un política de desmantelamiento de las instituciones públicas que tienen la obligación constitucional de prestar servicios sociales básicos a la población. El deterioro del salario directo e indirecto merma la capacidad de reproducción de la vida en condiciones dignas.

\section{Derrocamiento de la cultura material}

El despojo a diversas comunidades de los medios de vida y trabajo amparados en el régimen de propiedad social y colectiva destruye la cultura material de los pueblos y separa a los productores directos de los medios de producción para permitir a los capitales privados explotar libremente los bienes comunes naturales, la riqueza alojada en el entorno vital de las comunidades desahuciadas. Un ejemplo son los megaproyectos mineros, hidroeléctricos y eólicos que despojan tierras mediante métodos neocoloniales. El ecocido aflora como saldo de la degradación de bosques, contaminación de agua y aire; además de 
la pérdida de saberes ancestrales de los pueblos indígenas y campesinos (Toledo, 2015; Zambrano, 2013). Estas economías de enclave dejan a su paso pobreza, enfermedad y muerte, además de que favorecen la desarticulación de la vida comunitaria y la criminalización de la protesta. Para conseguir propiedades y concesiones, explotar la minería, el agua, la biodiversidad y los bosques, las multinacionales canadienses, estadounidenses, españolas y chinas se benefician del marco institucional y normativo dotado de instrumentos aprobados por el gobierno neoliberal como el TLCAN, la ley de inversión extranjera y la ley minera.

Los conflictos socioambientales se han incrementado en México durante los últimos 10 años. Está en disputa el acceso, control y gestión de los bienes comunes naturales, que para las comunidades representa el soporte material de la vida y para el capital significa insumos productivos consumibles en el menor tiempo posible en aras de maximizar las ganancias sin importar la lentitud del tiempo de reposición o que no sean renovables. El móvil de la disputa es el saqueo de la riqueza natural por capitales extractivos interesados en venderla como materia prima o transformarla en mercancía. El saqueo forma parte de cadenas globales de extracción, producción, circulación, consumo y desecho.

El extractivismo se remonta al proyecto histórico colonial que signa el surgimiento de América Latina hace más de cinco siglos. En la etapa neoliberal la extracción de bienes naturales, sean o no renovables, toma relieve con los megaproyectos de material de infraestructura (carretera, puertos y enclaves turísticos) y agronegocios a cargo de transnacionales que arrasan con los pequeños productores rurales.

La actualización y renovación del despojo de bienes comunes ha sido impulsada por las políticas del capital privado y la participación del Estado mediante diversas estrategias jurídicas y políticas como la cooptación, disciplinamiento y división de comunidades, la represión, criminalización, militarización y contrainsurgencia, todo para garantizar la apertura de nuevos espacios de explotación y mercantilización.

La apropiación y saqueo de la naturaleza y la acumulación de capital asociada adquieren ciertos aires de novedad (Galafassi y Composto, 
2013): los bienes naturales no renovables como petróleo, gas y minerales tradicionales están en curso de agotamiento, por lo que el descubrimiento y extracción de hidrocarburos no convencionales y minerales raros, recursos estratégicos en disputa, están respaldados con tecnologías predadoras y tóxicas — como la fractura hidráulica-; asimismo los bienes naturales renovables básicos — agua dulce, fertilidad del suelo, bosques y selvas - se están convirtiendo en no renovables y cada vez más son escasos, y los bienes naturales (renovables y no renovables) se convierten en mercancías (commodities), es decir, en una especie de activos financieros incrustados en espacios de inversión y especulación extraordinaria debido al alto y rápido nivel de ganancia que movilizan los «mercados de futuros», responsables del aumento ficticio de los precios de los alimentos y de las materias primas en el mercado internacional.

México encabeza el número de conflictos mineros en América Latinas: al menos 37 comunidades mexicanas están en pleito con empresas que tienen concesiones para la explotación minera en sus territorios (ocmal, s.f.), puesto que contaminan el medio ambiente e inhabilitan las tierras de cultivo, tema particularmente grave al tratarse de pueblos con altos índices de pobreza.

\section{El dominio del hambre}

Signada por el TLCAN, la apertura comercial indiscriminada abre las puertas a las agroempresas multinacionales para colocar mercancías y servicios en detrimento de la agricultura y la soberanía alimentaria de México. En esa lógica se desmantelan las instituciones que impulsaban la producción en el campo, como Banrural, Fertimex, Conasupo, Conafrut y la Productora Nacional de Semillas. Desde entonces el sector primario se caracteriza por el estancamiento, el despoblamiento y la dependencia alimentaria. El desmantelamiento de la institucionalidad agropecuaria sumió a la mayoría de los productores del campo en la bancarrota y desencadenó la migración hacia Estados Unidos. 
No obstante que el país es el decimocuarto productor agropecuario en el mundo, también es de los principales importadores de alimentos. México sufraga un alto costo comercial y productivo para complementar la canasta básica que consume la poblaciónः se importa 43 por ciento de los alimentos y cada año se realizan compras en el exterior por unos 15 mil millones de dólares, un monto aproximado a la principal fuente de divisas, los ingresos petroleros, y síntoma de la vulnerabilidad alimentaria que padece el país, según la Organización de las Naciones Unidas para la Alimentación y la Agricultura (FAO, por sus siglas en inglés) (Méndez, 2013).

Pese a que el país destaca ahora como exportador de productos llamados no tradicionales - p.ej., cerveza, tomate fresco, aguacate, berries, chiles y tequila-, los alimentos básicos que pudieran producirse tienen que importarse: en las últimas dos décadas la dependencia alimentaria se incrementó al pasar de 10 por ciento en 1994 a 43 por ciento en 2013. En ese lapso la producción de granos y oleaginosas creció 23.2 por ciento (pasó de 29.2 millones de toneladas en 1994 a 36 millones en 2013) pero la importación de alimentos básicos pasó de 17 a 33 por ciento en maíz; de 34 a 65, en trigo; de 60 a 85, en arroz, y se importó 95 por ciento de soya y 55 de algodón. Pese a ello, de acuerdo con cifras oficiales del INEGI, mientras que en 1994 se importaron alimentos por un total de mil 800 millones de dólares, en 2013 esa misma factura fue por 21 mil 407 millones, es decir, la balanza comercial agroalimentaria de México fue deficitaria por más de 3 mil 374 millones de dólares (Chávez, 2014).

Dado que es imposible producir el cúmulo de productos que demanda la población, ningún país puede contar con una soberanía alimentaria total, por lo cual es necesario recurrir al comercio internacional para complementar la canasta; sin embargo resulta suicida renunciar a la producción de alimentos básicos y estratégicos.

Adicto a la ideología del libre mercado, en lugar de buscar la soberanía alimentaria, México se hunde en la dependencia alimentaria. Hace más de tres décadas perdió la autosuficiencia alimentaria para dedicarse 
a comprar a otros países los productos básicos de la dieta nacional. Un grano básico y emblemático de la dieta, el maíz, arroja cifras anuales de producción de 21 millones de toneladas, pero se importan 10 millones de toneladas (Perea, 2015), circunstancia que deriva en una franca dependencia. La cadena de importaciones de productos básicos que pueden producirse con suficiencia en el país es larga: la tercera parte del maíz, la mitad del trigo, 80 por ciento del arroz, entre 30 y 50 por ciento del frijol y más de 30 por ciento de la leche en polvo. También se importa más de 80 por ciento de oleaginosas, sorgo y soya, que van destinadas a la alimentación animal y la producción de aceites, y pese a no ser productos básicos repercuten en la producción de huevo, carne de pollo y res, e indirectamente deterioran la seguridad alimentaria (Méndez, 2013).

\section{Exportación de trabajadores}

El campo mexicano, otrora reservorio de subsistencia social y fuente de alimentos para el resto de la población, fue prácticamente devastado por el modelo neoliberal. Los agricultores afrontaron con fuerte desventaja la política de apertura, los subsidiados productores estadounidenses que les competían y el desmantelamiento de las instituciones y políticas de fomento del sector. Luego de que en 2008 finiquitaron el régimen de protección a las tarifas de granos básicos como frijol y maíz, que pretendían conferir seguridad alimentaria, México se convirtió en importador neto de productos agrícolas merced a las políticas que intencionalmente buscaban ese cometido.

En el periodo neoliberal, entre 1983-2014, según cifras oficiales, alrededor de 12 millones de mexicanos emigraron al extranjero, sobre todo a Estados Unidos, en busca de un trabajo asalariado que no encuentran en México, además de que 58 por ciento de la población económicamente activa para 2014 se contaba en el sector informal. En tal sentido el grueso del «bono demográfico» se está transfiriendo al extranjero, principalmente a Estados Unidos. En suma, la economía mexicana transfiere sistemáticamente excedente económico y fuerza de trabajo. 
Los trabajadores migrantes radicados en el extranjero, sobre todo en Estados Unidos, envían recursos dinerarios a México, principalmente a sus dependientes económicos. Estos recursos complementan los gastos de subsistencia familiar y son un componente salarial que llena los vacíos de la economía mexicana. Según los datos del Banco de México, las remesas oscilan de acuerdo al ciclo económico y a las restricciones de la política migratoria. El flujo dinerario enviado por los migrantes muestra un comportamiento cíclico con efectos contrapuestos a la devaluación del peso. Entre 1982 y 2007, cuando alcanzaron su pico más alto, aumentaron de 1,043 millones de dólares (mdd) a 26 mil 49.6 mdd respectivamente, pero con la crisis cayeron a 21 mil 244.7 mdd en 2009, para luego mantener una tendencia estable de 21 mil 892.4 mdd con un repunte de 7 por ciento en 2014 (Calva, 2014).

La balanza de pagos se embarnece con las divisas generadas por la exportación de migrantes («migradólares»), un saldo monetario favorable con montos semejantes a los reportados por la venta de petróleo («petrodólares»), superiores al turismo y probablemente menores al dinero negro de la venta de drogas («narcodólares»); sin embargo la exportación de trabajadores tendría que estar considerada como un saldo social negativo producto del modelo neoliberal que entraña una estrategia de despojo y empobrecimiento junto a una incapacidad estructural para generar suficientes empleos formales de calidad (tipificada como pérdida de soberanía laboral), por lo cual se paga un alto costo socioeconómico al derrochar el «bono demográfico» a cambio de unos cuantos dólares.

El auge exportador de fuerza de trabajo migrante y el raquítico desempeño de la economía mexicana dentro del modelo neoliberal no son más que dos caras de la misma moneda devaluada. Los mismos organismos internacionales han reconocido que las remesas observan una correlación negativa frente al crecimiento económico y sólo compensan a las familias receptoras ante el deterioro económico prevaleciente (Chami, Fullenkamp y Jahjah, 2003), y a la postre el flujo de remesas entraña una nueva forma de dependencia. 


\section{Privatización de la esfera pública}

A partir de 1982, el Estado mexicano implementa un programa de privatización de áreas exclusivas y prioritarias. Las reformas neoliberales atacan el orden constitucional, las leyes secundarias y reglamentos. Mediante la venta directa, liquidación, transferencia, concesión y licitación, el número de empresas públicas pasó de 1,155 entidades a sólo 196 en 2012 (Sánchez, 2010). Con el programa de privatización de los gobiernos priistas y panistas, entre 1982 y 2012 las multinacionales y grupos nacionales se apropiaron de empresas públicas de sectores estratégicos que soportan el crecimiento económico. En tres décadas la privatización afectó a sectores y ramas económicos estratégicos como la siderurgia, banca, telefonía, ferrocarriles, carreteras, puertos marinos, aeropuertos, líneas aéreas, televisión, comunicación satelital, industria azucarera, entre otros. Además de la privatización silenciosa del sector energético (petrolero y eléctrico), ahora en ruta de descapitalización, endeudamiento y privatización.

Entre 1988 y 1993 el Estado transfirió al sector privado 50 por ciento de sus empresas, de las cuales 18 eran entidades financieras. Los bancos fueron recapitalizados y dotados de reservas para afrontar la deuda vencida y la interbancaria. Después, con el rescate de la banca, el Estado gastó dos o tres veces más el valor de lo que obtuvo por la venta. Otro ejemplo de privatización es la industria siderúrgica. Sidermex, un conjunto de tres siderúrgicas de administración federal -Altos Hornos, Fundidora Monterrey y Siderúrgica Lázaro Cárdenas-Las Truchas - fue vendida a la iniciativa privada por 755 millones de dólares. No obstante el costo en pasivos de las tres empresas superaba los 6 mil millones de dólares. La que por muchos años fuera la única empresa de telefonía, primero pública y luego privada, Teléfonos de México (Telmex) aplica tarifas altas comparadas con otros países, incluso con algunos de mayor poder adquisitivo. La privatización de los ferrocarriles empezó con los talleres de mantenimiento y la flota de locomotoras en 1994, actualmente el sistema ferroviario mexicano cuenta con dos ferrocarriles en manos extranjeras y otros dos en manos estatales. La Comisión 
Federal de Electricidad (CFE) sufre una privatización encubierta mediante la entrega de contratos a empresas extranjeras para la generación de energía eléctrica en el país, lo cual no se ha traducido en la reducción de los cobros excesivos por consumo de luz sino que van en aumento, además existen reportes de pérdidas (Sacristán, 2006).

De hecho, México destacó como el segundo país con más privatizaciones en la región. Según el Banco Mundial, en la década los noventa el gobierno mexicano transfirió activos por 31 mil 458 millones de dólares a particulares; esto representa 20.4 por ciento de la venta total de empresas propiedad del Estado en América Latina (González, Cason y Brooks, 2000).

El fracaso de algunos casos derivó en una espiral de privatización y reprivatización de bancos, carreteras e ingenios azucareros, además del rescate bancario Fobaproa-IPAB, según el principio de "socializar las pérdidas y privatizar los beneficios», donde en última instancia la sociedad paga la ineficiencia de las instituciones quebradas.

\section{Rescate público del sector privado}

Aunado a las políticas de austeridad que constriñen el gasto público y los capítulos de "desarrollo social», el gobierno aplica programas sin consulta pública para obligar, indirectamente, a la población contribuyente a pagar enormes rescates; entonces socializa (no por ser socialista) las pérdidas y privatiza las ganancias. Bajo esta estratagema el costo de los rescates del sector privado que se apropió de bancos, carreteras, ingenios azucareros y líneas áreas fue de 109 mil 214 millones de dólares; esta cantidad representa 3.4 veces el ingreso recabado en el programa de privatización de empresas públicas entre 1982 y 2003, y supera 38\% el saldo de la deuda externa del sector público (González, 2003).

Luego de la crisis económica de 1994, el gobierno mexicano aplicó un programa de rescate de la banca privada. El principal instrumentos fue la compra de cartera de los bancos mediante el Fondo Bancario de Protección al Ahorro (Fobaproa) y la capitalización temporal. El resca- 
te bancario significó un costo total de casi 70 mil millones de dólares, más elevado que los recursos que se obtuvieron por la venta de los 18 bancos nacionalizados en 1982, por un monto de 12 mil millones de dólares (Sánchez, 2010). Una de las principales causas de la crisis bancaria entre 1995 y 1997 es que en la privatización las autoridades privilegiaron el precio y vendiendo la banca al mejor postor, sin asegurar la experiencia de los nuevos banqueros ni el establecimiento de las operaciones y reglas que garantizan su viabilidad

\section{Deuda eterna}

El pago de la deuda externa se garantiza mediante las políticas de austeridad que ejercen un férreo control inflacionario, austeridad presupuestal y promoción del comercio exterior. Con datos del Banco Mundial, Toussaint estima que entre 1982 y 2000 la deuda se habría costeado más de ocho veces (González, 2002). En ese periodo la deuda casi se triplicó, al pasar de 57 mil millones de dólares a 157 mil millones, y el país transfirió 478 mil millones de dólares, es decir, el equivalente a 8.3 veces la deuda inicialmente contratada con los acreedores. La transferencia de excedente de múltiples países periféricos hacia los centros de la economía mundial son un mecanismos crucial para financiar los déficit gemelos, presupuestal y comercial, de Estados Unidos, que ejerce la supremacía gracias al poder del dólar como divisa internacional aunado al poderío militar, financiero y comercial (Varoufakis, 2015).

Entre 2000 y 2015, el pago de la deuda externa del sector público federal (amortizaciones de capital e intereses) representó siete veces el saldo del primer año. En ese periodo se transfirieron al exterior 516 mil 62.9 millones de dólares, equivalente a 43 por ciento del piв. No obstante el desembolso, el saldo actual duplica el registrado en 2000, por lo cual la obligación con los acreedores externos no tiene precedentes. En 2000 la deuda era de 70 mil 260.4 millones de dólares y a mediados de 2015 era de 158 mil 580.4 millones de dólares, es decir, creció 125 por ciento y alcanzó un récor histórico (González, 2015). 
Pese a ser continuamente presentado como «responsable» y "prudente» en el manejo de las finanzas públicas, de acuerdo a los montos de la deuda externa neta y los pasivos, excluyendo reservas internacionales y tenencias en oro, desde 2006 México forma parte de los 10 países con mayor deuda externa, en la octava posición. No obstante que el mismo Fondo Monetario Internacional (FMI) recomienda aplicar medidas de "desendeudamiento", los gobiernos del club de los endeudados aplican cambios mínimos en los pasivos externos e implementan medidas de austeridad que lesionan a las clases populares.

El país más endeudado del orbe es Estados Unidos, con 1,973 millones de dólares, equivalente a 14.2\% del PIB. Estos pasivos externos para 2013 sumaron 5,698 millones de dólares, equivalentes a 34\% del PIB. No obstante, Estados Unidos ha funcionado como el hegemón de la economía mundial y ha financiado sus deudas y déficits comercial y presupuestal engullendo el excedente generado en la economía global e imponiendo el poder del complejo industrial-militar, financiero con Wall Street a la cabeza y la supremacía del dólar como divisa internacional (Varoufakis, 2015). Si el comparativo se realiza en función del porcentaje del Pıв, España encabeza la lista en 2013 con pasivos externos equivalentes a 103\% del Piв. En 2006 México, con una deuda externa de 346,000 millones de dólares, se ubicaba por encima de Grecia, cuyos pasivos documentados sumaron entonces 237,000 millones de dólares. Comparativamente, la deuda griega en 2006 equivalía a 90.6\% del pib, contra la de México, que estaba en 35.6\% del piв. Con la deuda externa como proporción del PIB, México ocuparía el quinto puesto en 2013. Posteriormente, Grecia cayó en una profunda crisis financiera, la cual sería gestionada por la Troika con la imposición de severas medidas de austeridad. Claramente países deudores como España, Grecia y México están ubicados en otra posición, como economías periféricas y dependientes, a diferencia de Estados Unidos, el centro motor de la economía financiera. 


\section{Banca chupasangre}

A principios de los noventa, cuando comienza la privatización de la banca, se estipuló que el capital extranjero no controlaría más de 15 por ciento del capital bancario; una década después los bancos extranjeros tomaron el control mayoritario de la banca mexicana.

En México la banca configura un oligopolio. Desde hace 20 años los principales 25 bancos que operaban fueron fusionándose hasta reducirse a siete, sin contar a pequeños bancos con presencia marginal. Los españoles BBVA y Santander adquirieron Bancomer y Serfin, respectivamente; el canadiense Scotiabank compró Inverlat; el estadounidense Citigroup se adjudicó Banamex y el londinense HSBC tomó Bital. Según la Comisión Nacional Bancaria y de Valores (CNBV), los siete bancos más grandes poseen 84.1 por ciento de la cartera total de crédito y 89.4 por ciento de las utilidades de la banca comercial en México (Rodríguez, 2013). Entre 2007 y 2011 las utilidades netas de todos los bancos que operan en México sumaron 331 mil 925 millones de pesos, de los cuales los cinco bancos extranjeros más fuertes enviaron a sus casas matrices 167 mil millones de pesos.

La joya de la corona del grupo español вBVA es la filial mexicana Bancomer que aporta 45 por ciento de sus ganancias; en 2014 в BVA obtuvo una ganancia neta de más de 2,700 millones de euros (Carbajal, 2015). Durante lo más fuerte de la crisis, Bancomer transfirió recursos que permitieron mantener a flote al grupo financiero. Banamex es el segundo banco más importante del sistema financiero en el país, propiedad del estadounidense Citigroup, aunque atraviesa por un momento adverso por malos manejos administrativos. Antes la filial mexicana era ejemplar para Citi. Aun así, en 2014 el grupo ganó 7,313 millones. Banamex registra una aportación a la utilidad del grupo superior a 10 por ciento. En el tercer lugar del sistema bancario y el más importante de España es Santander México. En 2014 la utilidad total del grupo español fue de 5,816 millones de euros y la filial mexicana aportó cerca de 8 por ciento (Juárez, 2015), por lo que representa la 
tercera mejor filial en el mundo para ese corporativo: suele aportar 12 por ciento de las utilidades y América Latina en conjunto contribuye con 51 por ciento.

En medio de la crisis financiara las filiales extranjeras, destacadamente las mexicanas, han funcionando como flotadores para sus corporativos y han ayudado a apuntalar las inestables economías centrales, por lo cual las periferias están pagando el costo de la crisis generada por el capital mundial a costa de hundirse más en el subdesarrollo.

El capital financiero internacional controla las finanzas y socava la función de financiamiento a la actividad productiva; apenas contribuye con menos de 17 por ciento, uno de los aportes más bajos del mundo. Más de 90 por ciento de las ganancias de la banca provienen del endeudamiento de los hogares debido al cobro de intereses y comisiones, además de los recursos del rescate bancario.

El carácter oligopólico les permite imponer cobros muy altos, a nivel de usura: los bancos extranjeros aplican en México 21 comisiones extras que no pueden cargar en sus países de origen (Bravo, 2006). El crédito al consumo, mediante las tarjetas de crédito, es una de las actividades más lucrativas y las tasas de interés son de las más caras, oscilan entre 32 y 66 por ciento, por arriba de Canadá (18-20 por ciento), España (8-25 por ciento) y Estados Unidos (8-16 por ciento), e incluso de otros países como Colombia y Venezuela (Román y Merlos, 2008). En México, el margen de intermediación bancaria es muy alto; el cobro por otorgar créditos supera hasta veinte veces lo que pagan a los ahorradores, quienes obtienen rendimientos inferiores a la inflación (Rodríguez, 2013). Para empresas y personas acceder a un crédito es un suplicio, pues terminan por trabajar para cubrir las obligaciones con el banco bajo un régimen de "servidumbre por deudas». Las bajas tasas pagadas a quienes depositan su dinero inhiben el ahorro: según los datos del Banco Mundial, entre 2011 y 2015 el ahorro bruto como porcentaje del piв en México fue de 20 por ciento, por debajo del registrado en economías emergentes como China (49.9 por ciento), Corea (34.5) e India (29.3) (Banco Mundial, 2015a). 
Resultado de los intereses usurarios, el crédito es oneroso e incosteable. El nivel de penetración de la banca es raquítico, por lo que la gente tiene que recurrir a servicios financieros informales y las empresas al crédito de proveedores. El crédito interno al sector privado como porcentaje del PIB es exiguo, entre 2011 y 2015 representó 31.1 por ciento, mientras que en Corea fue de 138 (Banco, Mundial, 2015b). En esa medida, apenas 16.2 por ciento de las empresas utilizan a los bancos para financiar la inversión, por debajo de Brasil (48.4 por ciento).

En los últimos años todas las ramas productivas disminuyeron su participación. Entre 1995 y 2012 el crédito al sector agropecuario bajó de 5.2 a 1.6 por ciento; el industrial de 24.7 a 20.0 por ciento; el de servicios de 31.3 a 22.0 por ciento y el de vivienda de 21.4 a 16.7 por ciento; mientras tanto se incrementó el crédito al consumo de 5.3 a 21.2 por ciento al sector público de 4.0 a 13.2 por ciento, esto es, la banca privada privilegia el sector no productivo pero más rentable, como el crédito al consumo, o más seguro, como el sector público (Clavellina, 2013). Así pues, ellos deciden cuánto, a quién y en qué condiciones prestan dinero, siempre en función de sus expectativas de ganancia.

\section{Hacienda regresiva}

El sistema fiscal mexicano favorece a las grandes corporaciones que pagan los impuestos más bajos del mundo, además de que gozan de varios privilegios para evadir impuestos, diferir los pagos, alcanzar amnistía fiscal y obtener el reembolso de impuestos. El Código Fiscal de la Federación concede múltiples beneficios a las corporaciones para la devolución de recursos derivado de los rubros de Impuestos al Valor Agregado (IVA), el Impuesto Empresarial a Tasa Única (IETU) y el Impuesto Sobre la Renta (ISR), entre otros.

La Auditoria Superior de la Federación detectó a 20 grandes contribuyentes de las industrias alimentaría, telefónica, electrónica, cervecera, refresquera y minera, entre otras, que concentraron los mayores montos de devoluciones de impuestos en 2011 (63 mil 891 millones de pesos). 
Todo con base en un sistema fiscal que castiga presupuestalmente a Pemex e induce la descapitalización, endeudamiento y privatización, y un sistema que aumenta los impuestos a la población trabajadora y a los pequeños y medianos empresarios.

El sistema tributario mexicano se distingue por ser uno de los más ineficientes e injustos en el mundo. Como proporción del pib, la recaudación de impuestos es muy baja, tan sólo 19.7\%, incluyendo los ingresos petroleros; es de las más bajas de América Latina y de los países de la OCDE, donde se recauda un promedio de $34.1 \%$. Esta situación contrae el gasto social e impone restricciones en la política monetaria. El problema de fondo es la escasa base gravable gracias a los privilegios otorgados a una parte sustancial del ingreso nacional representado por el capital, lo cual restringe la capacidad recaudatoria y reproduce el círculo vicioso de baja recaudación, austeridad e inequidad social.

En cada ciclo parlamentario se busca gravar el consumo de alimentos y medicinas mediante el IVA, lo cual no se ha logrado, pero no se plantea resolver el problema de la petrolización de los ingresos públicos ni, lo más importante, la injusta distribución del ingreso.

\section{El motor económico del hampa}

La economía que gira en torno a la producción, comercialización y consumo de sustancias enervantes y estupefacientes consideradas ilegales está sujeta a persecución penal pero dinamiza al capitalismo global. Autoridades plegadas al conservadurismo toman como referente los daños en la salud pública y los efectos en las familias para decretar la ilegalidad de drogas como marihuana, cocaína, heroína y otras sustancias psicotrópicas, pero son más condescendientes con la existencia de un mercado de consumo compuesto por individuos y grupos sociales con cierto poder de compra, incluyendo algunas industrias, que hacen de las drogas una fuente de grandes rendimientos. Estados Unidos es el principal consumidor de drogas en el mundo (UNODC, 2014). La conjunción de la política prohibicio- 
nista y la demanda persistente en los países desarrollados como Estados Unidos, Inglaterra, Escocia y Australia propician altos precios de las drogas ilegales. Los grandes bancos globales y los paraísos fiscales realizan millonarias operaciones de lavado de dinero y el vinculado tráfico ilegal de armas es un gran negocio para países como Estados Unidos, Inglaterra, Rusia, Ucrania, China y Francia. Nada menos en Estados Unidos 40 fabricantes e importadores de armas comercializan 3 millones de armas que en conjunto reportan más de 30 mil millones de dólares anuales (Proceso, 17 de marzo de 2011). En los países subdesarrollados de la región andina (Colombia, Bolivia y Perú), Asia (Afganistán y Pakistán) y México, dada las condiciones estructurales de pobreza y desempleo, existen redes de productores de drogas que asumen los riesgos legales y represivos. Además algunos movimientos armados participan en la producción para financiar sus actividades político-militares.

La cadena de valor de la droga puede ser flexible en su etapa de producción y distribución, pero está propensa al control militar y sujeta a pactos entre organizaciones locales y transnacionales, lo cual la preña de una alta dosis de violencia. El papel del Estado es ambiguo pero determinante para el funcionamiento de la economía criminal, por una parte, tiene la obligación legal de cortar el circuito productivo y comercial, pero al no hacerlo por incapacidad o colusión, pierde legitimidad; por otra parte, las autoridades suelen participar al negociar, dirigir o pactar con las organizaciones criminales el tráfico de drogas y la distribución de los espacios de distribución, con lo cual se impone una especie de gobernanza mafiosa extralegal a costa de corromper el sistema político. La aparente estabilidad alcanzada por la connivencia entre el Estado y las organizaciones criminales que posibilita un control territorial y una disminución relativa de la violencia deriva en un «narco-Estado». La producción de enervantes como mariguana y amapola o la elaboración de heroína y metanfetaminas son actividades detonadoras de las economías locales y del tejido social impregnados de ese dinamismo, y por ello adoptan formas de socialización enmarcadas en la narcocultura, que a la postre redundan en formas diversas de degradación social y una espiral de violencia. 
El tráfico mundial de las drogas es uno de los circuitos comerciales más dinámicos de la economía global. La onu calculaba que movilizaba 500 mil millones de dólares en 1990 y 683 mil millones de dólares en 2013 , lo cual representa 1.5 por ciento del рів mundial, la mayor parte del dinero negro (70 por ciento) se blanquea en los circuitos financieros controlados por los grandes bancos globales y los paraísos fiscales. Los países que participan directamente en la cadena de valor desarrollan una dependencia de las drogas. Por ejemplo, la economía de las drogas tenía una alta participación en el "triángulo andino»: en los ochenta en Bolivia las drogas representaban 75 por ciento del PIB; en Colombia de 36 por ciento, y en Perú de 24 por ciento (Müller, 1994); en Afganistán la producción de heroína representa 9 por ciento del pi b para 2010 (unOdC, 2011).

Al enfocar la mirada en México, no existe mucha precisión sobre los datos clave de la economía criminal, pues las cifras dependen de la metodología, la fuente y el acceso a la información. Los datos son discordantes: desde estimaciones que atribuyen a las drogas una participación de 1 por ciento en el PIB, pasando por 7 por ciento, hasta elevarse a 40 por ciento. Las estimaciones más elevadas también consideran que 78 por ciento de las actividades económicas del país han sido infiltradas por el narcotráfico (Buscaglia, 2012), principalmente la minera, agropecuaria, farmacéutica, química y los fideicomisos (Gómora, 2012), además de que 72 por ciento de los 2,440 municipios están inmersos en las actividades ilícitas y 65 por ciento de las campañas electorales son contaminadas por el dinero sucio. De igual forma, algunas entidades del país están sometidas a un mayor influjo criminal, sobre todo en las costas del Pacífico y el Golfo de México.

En términos estructurales, en el contexto de una economía estancada y promotora de precariedad e inseguridad laboral, la economía de las drogas se ha convertido en la principal generadora de empleos donde se ocupan 600 mil mexicanos (Rodríguez, 2011) y una de las principales fuentes de divisas: las estimaciones oscilan entre 18 mil y 45 mil millones de dólares anuales (Franco, 2011). Incluso las organizaciones de 
criminales tienen sus propias bolsas de trabajo para reclutar personal especializado entre abogados, químicos, contadores, informáticos, constructores, arquitectos, agroquímicos, notarios, pilotos y administradores, además de que los médicos, enfermeras y técnicos en comunicación son amenazados para que brinden sus servicios (Gómora, 2014). También se engancha a personal para actividades menos especializadas, pero más violentas, como sicarios y escoltas, o se recluta a «mulas» que cruzan la droga hacia Estados Unidos, para ello incluso se publican avisos clasificados en los periódicos (Proceso, 11 de abril de 2012). Aunque también se estima que la violencia ha impactado de manera negativa en la producción, el empleo y la inversión, al P IB representan 12 por ciento (Robles, Calderón y Magaloni, 2013).

La economía política mexicana registra un flujo de divisas producto de las actividades ilícitas que genera fuentes de empleo y activa circuitos económicos formales e informales, pero lo hace a un costo humano y político muy alto: los delitos atentan contra la vida y tranquilidad de personas y comunidades, el tejido social se desbarata y el entramado institucional se precipita por una profunda crisis de legitimidad.

En la era del gran capital monopolista, México se está especializando como una economía productora, exportadora y consumidora de drogas. En el territorio mexicano, especialmente en las intrincadas zonas montañas florece el cultivo y procesamiento de amapola y mariguana; la capacidad instalada en laboratorios clandestinos permiten que se ocupe la segunda posición mundial como productor de heroína y que se fabriquen metanfetaminas a partir de precursores químicos importados por los puertos de Manzanillo y Lázaro Cárdenas desde Oriente (Velázquez, 2015). La geografía mexicana ha sido dibujada siguiendo las rutas de trasiego de cocaína proveniente de Sudamérica con destino a Estados Unidos, el mercado de consumo más grande del mundo. Pero también nuestro país está creciendo en importancia para el consumo de drogas, especialmente desde que las organizaciones de traficantes mexicanas comenzaran a recibir como pago de los exportadores colombianos no sólo dinero o armamento sino drogas, como forma de pago en especie. 
La actividad exportador es la más dinámica de la economía mexicana. Dentro de ella destaca la economía criminal. El Congreso mexicano estima que el crimen organizado representa 10 por ciento del PIB, es decir, 150 mil millones de dólares con una gran variedad de delitos: el tráfico de drogas aporta 40 o 45 por ciento; el tráfico de personas, de 30 a 32 por ciento; la piratería, 20 por ciento y otras actividades ilícitas como el secuestro y la extorsión, complementan la bonanza económica criminal (CESOp, 2012).

El rubro más boyante en la cartera de negocios de la mafia es el tráfico de drogas: los estupefacientes representan entre 60 mil y 70 mil millones de dólares. La ocupación de fuerza laboral es significativa, el personal en esta actividad se estima entre 450 mil y 500 mil, lo cual supera tres veces la nómina de Pemex, la empresa insignia del país y soporte histórico de la hacienda pública, al menos antes de que el actual gobierno termine por desmantelarla. En la era del capital monopólico y el trabajo precario, la economía mexicana sufre estancamiento crónico e incapacidad estructural para crear empleo formal de calidad, y resulta que el gran empleador emergente es nada menos que la economía criminal.

Uno de los negocios más redituables de la economía mundial, con flujos comerciales ascendentes, es el que representa el tráfico de drogas. El desarrollo desigual imprime un sello particular en la división del trabajo criminal y en la organización del proceso de valorización que entrevera circuitos financieros, industriales y comerciales de capitales que alternan entre la legalidad y la ilegalidad. Los países especializados en la producción y trasiego de estupefacientes están ubicados en las periferias y por su posición subordinada caen presas de una dinámica de violencia, corrupción y deterioro de las instituciones del Estado y el sistema político, a la vez que se envilecen las relaciones sociales y los procesos democráticos pierden sentido. Los grandes centros económicos del mundo son los mayores consumidores de drogas y los grandes operadores de la economía criminal, pues en su ámbito de influencia se concentran las grandes masas de ganancia y se lava dinero, pero también 
se venden armas y diseñan políticas de intervención militar y policial para las periferias; en los centros el efecto nocivo está más focalizado en grupos sociales adictos al consumo de drogas que por su marginación resienten daños en la salud personal y afectación en el ámbito laboral, educativo y familiar.

\section{Dinero negro progresivo}

La economía criminal arroja grandes cantidades de dinero «negro» que requieren ser «lavadas» para insertarlas en los circuitos financieros y económicos de la economía legal. Estas operaciones se realiza, principalmente, en alguno de los 73 paraísos fiscales, principalmente en Suiza, Luxemburgo, Hong Kong, Emiratos Árabes Unidos, Liberia, Nigeria, Islas Caimán y Estados Unidos. Estados Unidos es el centro financiero del mundo y receptáculo de los excedentes económicos generados en la mayor parte del orbe, lo cual incluye el dinero negro de la economía criminal. Estados Unidos estaría lavando la mayor parte del dinero mundial (Petras, 2001). Estos espacios denominados Centros Financieros Extraterritoriales (CFE) son jurisdicciones fiscales o demarcaciones acotadas legalmente que no exigen la residencia de los operadores financieros y representan una zona opaca con privilegios fiscales. Semejantes paraísos mueven cada años al menos unos 600 mil millones de dólares procedentes de actividades ilícitas como el narcotráfico, trata de blancas, trafico de personas o tráfico de armas, también encubren dinero producto de sobornos y corrupción, por lo que las sumas pueden alcanzar 1,500 millones de dólares. Se estima que la operación de lavado de dinero representa entre 2 y 5 por ciento del PIB mundial. El mercado mundial de las drogas ilegales forma parte esencial de la economía criminal global y del sistema capitalista mundial: ha procreado una fuerza industrial que soporta muchas economías nacionales y locales en diversas partes del mundo. Para el funcionamiento de la economía del narcotráfico es indispensable el funcionamiento libre o medianamente regulado de los paraísos fiscales, que en conjunto son una de las principales 
fuentes de liquidez del capitalismo contemporáneo conseguidas no a partir de la inversión, el trabajo y el ahorro, sino sobre la base del crimen, la violencia y la inseguridad.

Las corrientes de dinero ilícito soportan la economía del narcocapitalismo. Pujantes circuitos financieros y círculos empresariales, políticos y judiciales que actúan en ámbitos impregnados por la respetabilidad burguesa están irrigados por esa liquidez espuria. Las mejores artes de la gestión empresarial imprimen bríos al negocio de los narcóticos y otros delitos asociados; por lo que no es extraño que el comportamiento de la economía criminal tenga semejanza con el patrón capitalista: promueven sus productos y sacan al mercado productos nuevos, disputan el mercado entre empresas, reinvierten parte de sus ganancias y acumulan grandes fortunas; sin embargo es un negocio peculiar porque sus productos representan un peligro para la salud pública, recurren a la violencia armada para controlar los mercados, no pagan impuestos pero sí sobornos. El esquema de negocios impulsa a diversificar la comisión de delitos para reducir los costos de producción, de manera que simultáneamente pueden traficar droga y personas aprovechando las rutas, redes de protección y logística. Obviamente el capital criminal está compenetrado en la dinámica global del capital. Las empresas criminales operan diversos giros de negocio, además de la consabida venta de droga o contrabando trafican drogas, personas y órganos; también se dedican a la trata de mujeres y otras actividades lícitas. Una característica peculiar es que en éstos sectores fluye mucho efectivo, como en la actividad turística y su racimo de hoteles, centros nocturnos, alquileres de autos y restaurantes; el mercado inmobiliario, la compraventa de carros, joyerías y obras de arte; aunque la mayor parte de transacciones monetarias se canalizan mediante bancos, remesadoras, casas de cambio y empeño. El flujo compulsivo de dinero sucio transita de la ilegalidad a la legalidad con rapidez y sin dejar huella con el solo cometido de valorizarlo según la lógica del dinero progresivo.

A partir de investigaciones del Senado de Estados Unidos sobre operaciones de lavado de dinero en Medio Oriente y México, el banco 
británico HSBC aceptó haber lavado miles de millones de dólares procedentes del narcotráfico, contrabando de armas y terrorismo. En particular desde las sucursales mexicanas se habrían enviado a Estados Unidos siete mil millones de dólares sólo de 2007 a 2008 para su blanqueo. Sin embargo la multa de 1 mil 900 millones de dólares impuesta a HSBC en Estados Unidos equivale a sólo cinco semanas de ingresos del banco y a menos de 10 por ciento de sus ganancias de capitalización de un semestre (Redacción AN, 14 de diciembre de 2012). El Banco pagó una multa de apenas 369 millones de pesos a la Comisión Nacional Bancaria y de Valores de México por el lavado de dinero (González, 26 de julio de 2012). Más adelante, para contener las reiteradas acusaciones de lavado de dinero, el banco ha tenido que pagar para que las investigaciones en su contra se cierren, como lo hizo con la Fiscalía General de Ginebra a quien pagará 43 millones de dólares. También BanamexCitigroup ha sido investigado y multado por operaciones de lavado de dinero (Bloomberg, 2015).

Empresarios de cuello blanco y narcotraficantes asoman la cabeza en la hidra criminal que se alimenta de dinero turbio y engulle a diversos sectores sociales. Ante el clima de inseguridad y la impotencia del Estado, algunos empresarios mexicanos han establecido pactos con el crimen organizada para obtener los servicios de transporte, protección, comercialización y custodia. En el extremo, la prestación de servicios abarca actividades propias de una empresa capitalista, pero por otros medios, como el cobro extrajudicial o la eliminación de competidores. Además se realizan alianzas para incurrir en el robo y venta de combustibles y minerales, un filón del pujante extractivismo.

La clase política también se ha aceitado con el dinero ilícito. La campañas electorales de todos los partidos están financiadas por organizaciones criminales y las autoridades, mandos militares y policiales son sobornados. Para que el dinero se destile a las alcaldías, gubernaturas, legislaturas, magistraturas y otras instituciones los beneficiarios requieren que perdure la corrupción y la impunidad. El sistema político mexicano está compenetrado por la economía criminal y sus circuitos 
dinerarios empapan las instancias de representación y las procuración de justicia.

\section{CONCLUSIÓN}

Con todo, la buena gobernabilidad, precepto caro a la ideología dominante, se hace pedazos con las múltiples señales de la profunda crisis: a) el Estado ha sido capturado por el poder del capital monopolista (especulativo, extractivo, maquilador, criminal) que ha vaciado de contenido y pertinencia social al entramado institucional y los procesos democráticos; $b$ ) los potentados se enaltecen y enriquecen con la corrupción imperante a costa del descrédito público, la perversión de la representación política y la derechización del sistema de partidos; c) las reformas neoliberales amplían los espacios de valorización del capital en detrimento del desarrollo humano, el bien común, la justicia social y la democracia; d) el mantenimiento del orden establecido mediante políticas coercitivas y punitivas que incluyen la criminalización de los pobres, la censura de medios de comunicación y la exclusión de grandes sectores a una educación pública de calidad; e) el Estado se confunde con el crimen organizado, no sólo porque la violencia estatal, los operativos policiaco-militares y los grupos delictivos hacen fuego cruzado teniendo a la sociedad civil en medio sino también por la corrupción rampante en los ámbitos gubernamental, legislativo y judicial que en colusión con grupos financieros y empresariales incurren en la comisión de delitos para amasar fortunas sin importar que con ello se destruyan vidas humanas, se desmorone el principio de convivencia pacífica y el miedo adquiera la ralea de dispositivo de una gobernanza autoritaria.

Cuando impusieron el modelo, los promotores nacionales adictos a la ideología neoliberal propalaron un magnificente discurso que anunciaba el nuevo mantra del desarrollo con la apertura de la economía al exterior, la desregulación de la actividad empresarial y la privatización de los activos públicos. Para quien se dejara seducir, el futuro parecía prometedor, pues la anquilosada economía nacional postrada en el atra- 
so sería preñada de nuevos bríos y más pronto que tarde el país recobraría la capacidad de crecimiento, crearía suficientes empleos formales de calidad, recuperaría el nivel de los salarios reales y terminaría con el fantasma de la pobreza que asolaba a la mayoría de la población. En una palabra, el país se modernizaría.

La testaruda realidad ha desmentido puntualmente el discurso oficial durante los más de treinta años. En lugar de que se ejecutara la sinfonía del crecimiento económico se escuchan las lánguidas notas de un estancamiento crónico con pautas de 2.4 por ciento de crecimiento promedio anual del producto interno bruto (PIB); la promesa de abrir fuentes de empleo para todos se ha topado con un régimen de empleos de la peor calaña: informales, precarios e inseguros, y el síndrome de la desesperanza aflora con la propagación del desempleo, la migración y la criminalidad; lejos de incrementar el poder adquisitivo de los asalariados y mejorar la calidad de vida del pueblo, la estrepitosa caída libre del salario real alcanza 78 por ciento desde principios de los ochentas y el fantasma de la pobreza cubre a casi 70 por ciento de la población, una parte de la cual padece las peores condiciones de hambre; en lugar de configurar un sistema productivo articulado y equilibrado el capital productivo cambió de rosto al extranjerizarse y empeoró la enfermedad de la «heterogeneidad estructural», las cadenas productivas fueron resueltamente desmanteladas como si fuesen tumorales, la desindustrialización adquirió el nombre de maquiladora y la agricultura tradicional fue enterrada.

De acuerdo a su propia mística, no es osado decir que el modelo neoliberal ha sido exitoso, pues se trata de un proyecto de clase - no de un proyecto para generalizar el desarrollo humano- que sólo pretende reconcentrar el ingreso, el poder y la riqueza (Harvey, 2007) en manos de una delgada élite social, privatizar bienes públicos y comunes, abrogar derechos sociales y subordinar a la mayoría de las clases sociales. Los más ricos se han convertido en multimillonarios (llámese plutocracia o plutonomía) y figuran en las listas anuales de los hombres más ricos del planeta (por más que la metodología de esas publicaciones sea cuestionable). 
El derrotero de la economía mexicana se ha traducido en la polarización extrema de la sociedad mexicana entre un minúsculo grupo de ricos y una gran masa empobrecida. Entre los más afectados están, por ejemplo, los jóvenes que no pueden acceder a un trabajo o a la educación, y no por decisión individual sino por una exclusión deliberada del modelo económico. La expansión de la pobreza ha sido tratada con programas de subsidios focalizados que no cambian las condiciones de vida, pero generan una base social de respaldo al régimen económico-político, amén de que los pobres son un mercado cautivo para usureros, la nueva banca y las microfinanzas, que en conjunto promueven la llamada servidumbre por deudas, sintetizada en el eslogan "pagos chiquitos» que a la postre significan, aún percibiendo un salario insuficiente, la erogación de montos varias veces mayores al precio real del producto o servicio consumido.

El desmadejamiento del tejido social y la exclusión social forman un caldo de cultivo para la propagación de múltiples actividades delictivas y propicia que las organizaciones criminales recluten entre los excluidos a los nuevos miembros que caen seducidos por la promesa del dinero fácil y el tren de vida acelerado, sin importan que la ofrenda al dios del dinero sea la destrucción de vidas humanas.

El saqueo deliberado del país por el neoliberalismo económico excluye toda posibilidad de desarrollo económico y social y de protección a la naturaleza. Las transformaciones económicas y las reformas que las acompañan tienen como propósito asegurar y legalizar el despojo y la explotación de las riquezas del país y del fondo de vida de la población, todo a nombre de la modernidad y el progreso.

\section{REFERENCIAS}

ASF (Auditoria Superior de la Federación) (2011), Análisis del informe de resultados de la fiscalización superior de la cuenta pública 2009, en LVI Legislatura, en: www3.diputados.gob.mx/camara/.../UEC0102011conclusiones_CPCP.pdf 
(2011), Análisis del resultado de la fiscalización superior de la Cuenta Pública 2009. Conclusiones y recomendaciones a la Auditoría Superior de la Federación, México, Cámara de Diputados.

Banco Mundial (2015a), «Ahorro interno bruto (\% del рів)», Datos, en: http:// datos.bancomundial.org/indicador/NY.GDS.TOTL.ZS.

(2015b), «Crédito interno al sector privado (\% del PIB)», Datos, en: http://datos.bancomundial.org/indicador/FS.AST.PRVT.GD.ZS.

Bloomberg (23 de noviembre de 2015), «Así era el lavado de dinero dentro de Banamex USA», El Financiero, en: http://www.elfinanciero.com.mx/bloomberg/asi-era-el-lavado-de-dinero-dentro-de-banamex-usa.html

Bovero, Michelangelo (2003), Una gramática de la democracia. Contra el gobierno de los peores, Madrid, Trotta.

Bravo, Mónica (2006), «Bancos cobran en México hasta 21 comisiones extra», Crónica, en: http://www.cronica.com.mx/notas/2006/223446.html

Buscaglia, Edgardo (2012), «La paradoja mexicana de la delincuencia organizada: policías, violencia y corrupción», Revista policía y seguridad pública,

Calva, José Luis (2014), «Dilapidación del bono demográfico y costos sociales del neoliberalismo», Trabajadores, núm. 105.

Сам (Centro de Análisis Multidisciplinario) (2014), «México: Fábrica de pobres. Cae $77.79 \%$ el poder adquisitivo. Reporte de Investigación 116», en: http:// cam.economia.unam.mx/mexico-fabrica-de-pobres-cae-77-79-el-poder-ad quisitivo-reporte-de-investigacion-116/

(2014a), «El Salario Mínimo en México: de la pobreza a la miseria. Pérdida del 78.66\% del poder adquisitivo del salario», en: http://cam.economia. unam.mx/el-salario-minimo-en-mexico-de-la-pobreza-la-miseria-perdidadel-78-66-del-poder-adquisitivo-del-salario-reporte-de-investigacion-117/

Carbajal, Braulio ( 5 de febrero de 2015), «La filial de México aporta 45\% de la ganancia de BBVA España», Milenio, en: http://www.milenio.com/negocios/ ganancias_BBVA_Espana-BBVA_Mexico_0_458954109.html

Carmona, Fernando, Montaño, Guillermo, Carrión, Jorge y Aguilar Alonso (1970), El milagro mexicano, México, Editorial Nuestro Tiempo.

Carpizo, Jorge (2006), El presidencialismo mexicano, México, Siglo xxi.

Cesop (Centro de Estudios Sociales y de Opinión Pública) (2012), Lavado de dinero: indicadores y acciones de gobierno binacionales, México, LXI Legislatura Cámara de Diputados.

Chami, Ralph, Fullenkamp, Connel y Jahjah, Samir (2003), «Are Immigrant Remittance Flows a Source of Capital for Development?», IMF Working Paper, WP/03/189. 
ChÁvez, Héctor (28 de octubre de 2014), «Dependencia agroalimentaria pasó del 10 al 43\% en 20 años», El Financiero, en: http://www.elfinanciero.com.mx/ economia/dependencia-agroalimentaria-paso-del-10-al-43-en-20-anos.html

Chávez, Helena (2013), «Necropolítica. La política como trabajo de muerte», Ábaco, núm. 78.

Clavelina, José Luis (2013), «Crédito bancario y crecimiento económico en México», Economía informa, núm. 378.

Dussel, Enrique (2006), 20 tesis de política, México, Siglo XXI.

El economista (4 de abril de 2013), «México, más barato que China en mano de obra: Bank of America», en http://eleconomista.com.mx/industrias/2013/04/04/ mexico-mas-barato-que-china-mano-obra-bank-of-america

Forbes (16 de diciembre de 2013), «Los 35 mexicanos más ricos», Forbes, en: http:// www.forbes.com.mx/los-35-mexicanos-mas-ricos/

Franco, Fernando (20 de junio de 2011), «Se lavan en México 45 mil millones de dólares; estiman», Excelsior, en: http://www.excelsior.com.mx/2011/06/20/ dinero/746081

Galafassi, Guido y Composto, Claudia (2013), «Acumulación por despojo: el caso de la minería a gran escala en la Patagonia», Cuadernos del CENDEs, vol. 30, núm. 83.

Garduño, Roberto, Méndez, Enrique y González, Roberto ( 9 de septiembre de 2015), «Funcionarios de primer nivel, senadores y diputados mantienen sus altos salarios», La Jornada, p. 6, en: http://www.jornada.unam. $\mathrm{mx} / 2015 / 09 / 09 /$ politica/006n1pol

Gómora, Doris (25 de mayo de 2014), «Cárteles tienen su 'bolsa de trabajo'», El Universal, en: http://archivo.eluniversal.com.mx/nacion-mexico/2014/impreso/carteles-tienen-su-8216bolsa-de-trabajo-8217-215831.html

(5 de noviembre de 2012), «Cárteles permean economía: Buscaglia», El Universal, en: http://archivo.eluniversal.com.mx/nacion/201538.html

GonzÁlez, Roberto (2002), «México ha pagado ocho veces su deuda externa en dos décadas», La Jornada, en: http://www.jornada.unam.mx/2002 /08/26/020n1eco.php?origen=index.html

(2003), «Los fracasos de particulares han costado al país 109 mil 214 mdd», La Jornada, en: http://www.jornada.unam.mx/2003/07 /25/020n1eco.php?origen $=$ economia.php\&fly=

(2003), «Los fracasos de particulares han costado al país 109 mil 214 mdd», La Jornada, en: http://www.jornada.unam.mx/2003/07 /25/020n1eco.php?origen $=$ economia.php\&fly= 
(2015), «En 15 años se ha pagado 7 veces el monto de la deuda externa», La Jornada, en http://www.jornada.unam.mx/2015/09/05/ economia/025n1eco

González, Roberto, Cason, Jim y Brooks, David (2000), «México, segundo privatizador de AL en la década de los 90: BM», La Jornada, en: http://www. jornada.unam.mx/2000/04/16/eco1.html

González, Susana (26 de julio de 2012), «Con multas por \$379 millones cierran caso de lavado en HSBC», La Jornada, en: http://www.jornada.unam. $\mathrm{mx} / 2012 / 07 / 26 /$ economia/027n1eco

Guerrero, Isabel, Luis López y Walton, Michael (2006), «La trampa de la desigualdad y su vínculo con el bajo crecimiento en México», Working Paper, World Bank, Representación en México, en: http://siteresources.worldbank. org/INTMEXICOINSPANISH/Resources/walton-espanol-24-11.pdf

Guillén, Arturo (2012), «México, ejemplo de las políticas anti-desarrollo del Consenso de Washington», Estudos Avançados, vol. 26, núm. 75.

Harver, David (2004), El nuevo imperialismo, Madrir, Akal. (2007), Breve historia del neoliberalismo, Madrid, Akal.

Huntington, Samuel (1993), «¿Choque de civilizaciones?», Foreign Affairs, JuÁrez, Edgar (2015), «México, una joya para los bancos extranjeros», El Economista, en: http://eleconomista.com.mx/sistema-financiero/2015/03/17/ mexico-joya-bancos-extranjeros

López Villafañe, Víctor (1986), La formación del sistema político mexicano, México, Siglo XXI.

MÁrquez, Humberto (2015), «La razón criminal del narcocapitalismo», Observatorio del desarrollo, vol. 4, núm. 14.

Martínez, David (11 de noviembre de 2015), «El PRI vuelve 'prócer' al dueño de Palacio de Hierro y 2do. Más ricos del país: le da la Belisario», Sin embargo, en: http://www.sinembargo.mx/11-11-2015/1548079

Мвемве, Achille (2012), «Necropolítica, una revisión crítica” en Chávez, Helena y Jezik, Enrique, Estética y Violencia: necropolítica, militarización y vidas lloradas, México, Museo Universitario Arte Contemporáneo/Universidad Nacional Autónoma de México.

Méndez, Ernesto (2013), «Es hora de ir al grano; México importa 43\% de los alimentos», Excelsior, en: http://www.excelsior.com.mx/nacional/20 13/05/05/ 897514

Monterroso, Augusto (1969), La oveja negra y demás fábulas, México, Joaquín Mortiz. 
Müller, Luis (1994), El imperio de la razón. Drogas, salud y derechos bumanos, México, unam.

ocmal (Observatorio de Conflictos Mineros de América Latina) (s.f. ), Mapa de conflictos mineros, proyectos y empresas mineras en América Latina, en: http:// mapa.conflictosmineros.net/ocmal_db/

Perea, Ernesto (11 de enero de 2015), «México importó 45\% más maíz en 2014», ImagenAgropecuaria.com, en: http://imagenagropecuaria.com/2015/mexicoimporto-45-mas-maiz-en-2014/

Petras, James (2001), «Estados Unidos, un imperio financiado con 'dinero sucio’», Proméxico (s.f.), «Fortalezas de México», en: http://mim.promexico.gob.mx/ work/sites/mim/resources/LocalContent/210/2/FortalezasMexico.pdf

Proceso (11 de abril de 2012), «Recluta narco 'mulas' por medio de anuncios clasificados, alerta EU», Proceso, en: http://www.proceso.com.mx/303980/recluta-narco-mulas-por-medio-de-anuncios-clasificados-alerta-eu

(17 de marzo de 2011), «Las aduanas,, coladera para las armas», Proceso, en: http://www.proceso.com.mx/265106/265106-las-aduanas-coladera-para-las-armas

Redacción AN (14 de diciembre de 2012), «Multa a HSBC por lavado de dinero es "irrisoria": Buscaglia», Aristegui Noticias, en: http://aristeguinoticias.com /1412/mexico/multa-a-hsbc-por-lavado-de-dinero-es-irrisoria-buscaglia/

Reuters (2013), «En México la mano de obra es más barata que en China», $L a$ Jornada, en: http://www.jornada.unam.mx/2013/04/05/economia/027n3eco

Robles, Gustavo, Calderón, Gabriela y Magaloni, Beatriz (2013), Las consecuencias económicas de la violencia del narcotráfico en México, Washington, BID:

Rodríguez, Arturo (8 de septiembre de 2014), «"Me sostengo" en lo dicho, "la corrupción es cultural': Pena Nieto», Proceso, en: http://www.proceso.com. $\mathrm{mx} / 381646 / \mathrm{me}$-sostengo-en-lo-dicho-la-corrupcion-es-cultural-pena

Rodríguez, Israel (2011), «El narcotráfico, el que genera más empleos: 600 mil, afirma experto», La Jornada, en http://www.jornada.unam.mx/2011/07/17/ economia/024n1eco

(2013), «Bancos cobran hasta 20 veces más de lo que pagan a los ahorradores», La Jornada, en: http://www.jornada.unam.mx/2013/05/19/ economia/027n1eco

Román, Romina y Merlos, Andrea (2008), «Más 'candados' a uso de tarjetas», El Universal, en: http://archivo.eluniversal.com.mx/finanzas/68074.html

Roux, Rhina (2012), «México: despojo universal, desintegración de la república y nuevas rebeldías», Theomai, núm. 26. 
SACristán, Emilio (2006), «Las privatizaciones en México», Economía unam, vol. 3, núm. 9 .

SÁnchez, José Juan (2010), La privatización en México como retracción estatal, México, IAPEM.

Solís, Juan y Acosta, Mariana (2015), «Peña Nieto y Televisa: ¿La construcción de un presidente?», Iberófrum. Revista de Ciencias Sociales de la Universidad Iberoamericana, vol. X, núm. 19.

Toledo, Víctor (2015), Ecocidio en México, México, Grijalbo.

Turrent, Eduardo (2007), «Historia sintética de la banca en México», Banco de México, en: http://www.banxico.org.mx/sistema-financiero/material-educa tivo/basico/\%7BFFF17467-8ED6-2AB2-1B3B-ACCE5C2AF0E6\%7D. pdf.

unodc (2014), World Drug Report, 2014, Viena, onu.

unOdC (Oficina de la onu contra la Droga y el Delito) (2011), «Afganistán: Aumenta un 7\% cultivo de opio, señala UNODC», en: http://www.un.org/spanish/News/story.asp?NewsID=21981\#.VtpO67zJCUc

Varoufakis, Yanis (2015), El minotauro global, Lugar, Crítica.

Velázquez, Enrique (2014), «México en la globalización: pasado, presente y futuro. Crisis civilizatoria», El Cotidiano, núm. 187.

Velázquez, Rogelio (2015), «Michoacán, el reino de los narcolaboratorios», El Universal, en: http://www.eluniversal.com. $\mathrm{mx} /$ articulo/periodismo-de-investigacion/2015/10/18/michoacan-el-reino-de-los-narcolaboratorios

Zambrano, Xochitl (2013), «Megaproyectos hídricos y mineros. 'Los pueblos indígenas vivimos despojo de nuestras tierras y una nueva colonización'», En el volcán, núm. 20. 
